Portland State University

PDXScholar

Dissertations and Theses

Dissertations and Theses

$11-5-1993$

\title{
Determining the Property Value Impact of Landfills
}

Okwuchukwu Gerald Uba

Portland State University

Follow this and additional works at: https://pdxscholar.library.pdx.edu/open_access_etds

Part of the Public Administration Commons, Public Policy Commons, Urban Studies Commons, and the Urban Studies and Planning Commons

Let us know how access to this document benefits you.

\section{Recommended Citation}

Uba, Okwuchukwu Gerald, "Determining the Property Value Impact of Landfills" (1993). Dissertations and Theses. Paper 4751.

https://doi.org/10.15760/etd. 6640

This Dissertation is brought to you for free and open access. It has been accepted for inclusion in Dissertations and Theses by an authorized administrator of PDXScholar. Please contact us if we can make this document more accessible: pdxscholar@pdx.edu. 
DETERMINING THE PROPERTY VALUE IMPACT OF LANDFILLS

by

OKWUCHUKWU GERALD UBA

A dissertation submitted in partial fulfillment of the

requirements for the degree of

\author{
DOCTOR OF PHILOSOPHY \\ in \\ URBAN STUDIES
}

Portland State University

1994 


\section{DISSERTATION APPROVAL}

The abstract and dissertation of Okwuchukwu Gerald Uba for the Doctor of Philosophy in Urban Studies was presented November 5, 1993 and accepted by the dissertation committee.

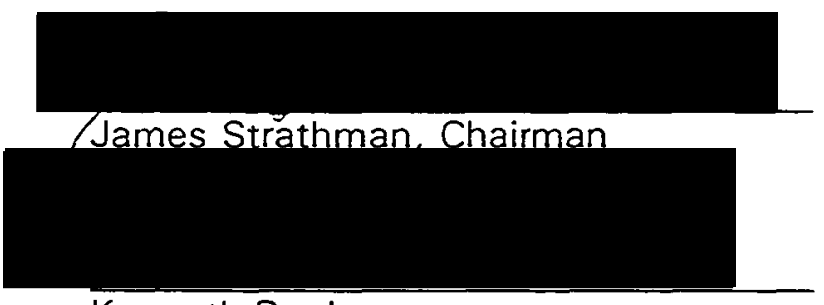

Kenneth Dueker

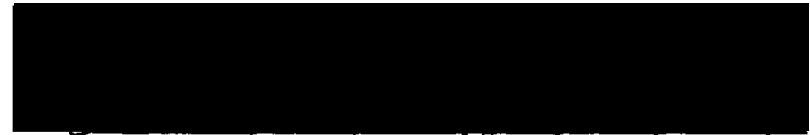

William. Rabiega

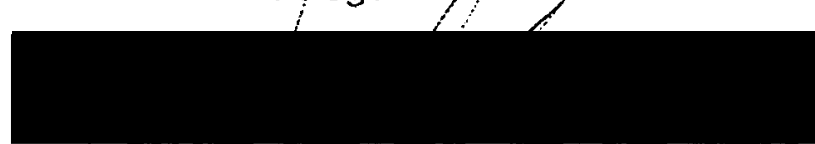

Nohad A. Tovan

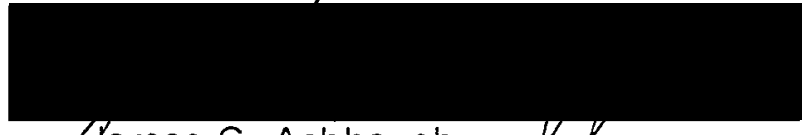

Sames G. Ashbaugh VV

Representative of the Office of Graduate Studies

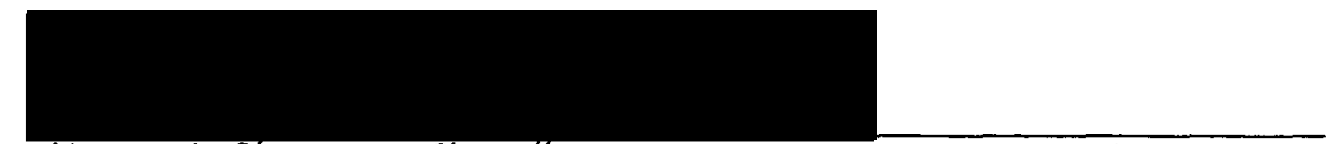

Nancy J. Chapman, Coord Knator, Ph.D. Program in Urban Studies

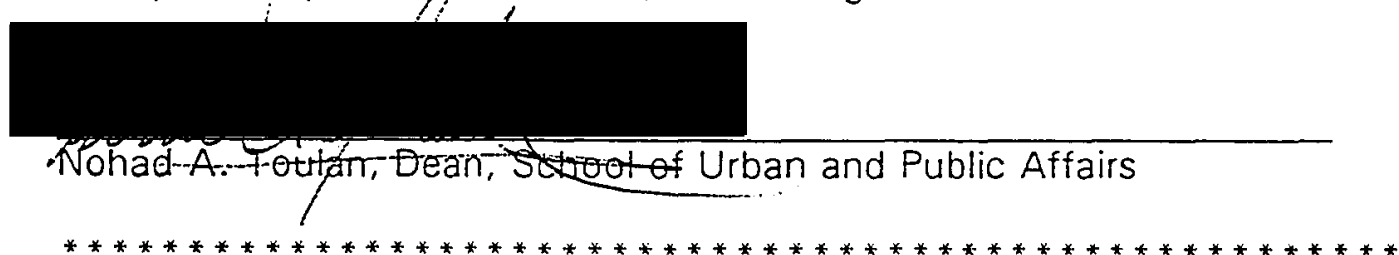

ACCEPTED FOR PORTLAND STATE UNIVERSITY LIBRARY

on 9 Qune 1994 
ABSTRACT

An abstract of the dissertation of Okwuchukwu Gerald Uba for the Doctor of Philosophy in Urban Studies presented November 5, 1993. Title: Determining the Property Value Impact of Landfills

The decline in property value can be due to owner's act or exogenous act from the operation of landfills. Landfill neighbors, especially home owners, perceive landfill operation to pose environmental safety problem such as ground water contamination and methane gas leakage that could affect home value.

Owners of landfills, especially those landfills that accept only dry waste (limited purpose landfill), claim that since their facilities meet the requirements of environmental regulations and the type of waste they accept could not possibly produce methane gas and leachate there is no property value impact of their facilities.

Several studies have shown that landfilis do not have impact on property value. However, one recent study found that a large regional landfill have impact on property value. 
The property value impact of a limited purpose landfill located in Portland, Oregon, was investigated in this study. Data were gathered for homes in approximately one half mile radius around the landfill for the periods before the landfill opened, during operation, and after closure.

Hedonic estimation technique incorporated in a multiple linear regression was used to control for a key variable (proximity or distance between the landfill and homes) and examine the relationship of this variable and sale price of homes. The results show that distance of homes (the proxy for perception) from the landfill was positively related and statistically significant with sale prices of homes during the period the landfill was in operation. Distance of homes sold in the periods the landfill was not in existence or operation was not positively related nor statistically significant with sale prices. That is, the operational effects of the landfill was capitalized into property value.

With this result, the issue of whether neighbors of landfills should be compensated deserve more attention. The results of this study would be very helpful in negotiating compensation. The results also show that if adequate pollution mitigation measures are in place landfill zoning ordinance should be based on the fact that landfill sites would yield maximum economic benefit to the owner after closure. 


\section{DEDICATION}

This work is dedicated to my father, Paul Uba-Okoh, and mother,

Margaret Nwanyiotube Uba-Okoh, for their faith in me and living through this work with me. 


\section{ACKNOWLEDGMENT}

To Dr. James Strathman, my advisor, I express my sincere appreciation for his constant support and direction that he provided me throughout my doctoral study at Portland State University. I am also grateful for Dr. Nohad Toulan, Dean of the School of Urban and Public Affairs, for his guidance, constructive critique of my academic work and professional practice. Appreciation is also extended to Dr. William Rabiega for helping to guide my quantitative analysis, and to Dr. Kenneth Dueker and Dr. James G. Ashbaugh for the time they spent reviewing and commenting on this dissertation.

Most of the data used in this study was provided by staff of the Oregon Multiple Listing Service. Their cooperation and support made this study possible.

My heartfelt appreciation must be extended to my beloved wife, Dr. Angela ljeoma Uba, and our children whose future education, I hope, will be inspired by this work. My wife's love, encouragement and understanding motivated me to complete this study while keeping my fuli-time professional job.

Finally, special thanks and appreciation go to the following for all kinds of support and closeness to me: Uncle Peter Minweh; Chief Moses Onuzulike; parents in-law Chief Boniface Ahanotu and Chief (Mrs) Martina Ahanotu; and "Grandfather" Gerald Ubazi, and also to Sherrie Blackledge and Aletta Yantis who used their superb secretarial skills to help me package this document. 
ACKNOWLEDGEMENT $\ldots \ldots \ldots \ldots \ldots \ldots \ldots \ldots \ldots \ldots \ldots \ldots \ldots$

LIST OF TABLES $\ldots \ldots \ldots \ldots \ldots \ldots \ldots \ldots \ldots \ldots \ldots \ldots \ldots \ldots \ldots \ldots \ldots$

LIST OF FIGURES $\ldots \ldots \ldots \ldots \ldots \ldots \ldots \ldots \ldots \ldots \ldots$ viii

\section{CHAPTER}

I INTRODUCTION .........................

The Problem $\ldots \ldots \ldots \ldots \ldots \ldots \ldots \ldots \ldots \ldots \ldots \ldots$

The Objective of the Study $\ldots \ldots \ldots \ldots \ldots \ldots \ldots$

Research Methodology ................... 9

Summary of Findings $\ldots \ldots \ldots \ldots \ldots \ldots \ldots \ldots \ldots$

II REVIEW OF LITERATURE: THE THEORETICAL BASIS FOR

PROPERTY VALUE, LANDFILL LOCATION AND IMPACT . . . . . . 11

Theoretical Foundations of Property Value $\ldots \ldots \ldots \ldots \ldots 11$

Theoretical Foundations of Landfill Siting and Impact . . . . . . 24

Landfill location and Impact Mitigation . . . . . . . . . 30

Previous Studies of Landfills Impact . . . . . . . . . . . . 39

Summary $\ldots \ldots \ldots \ldots \ldots \ldots \ldots \ldots \ldots \ldots \ldots \ldots \ldots \ldots \ldots \ldots \ldots$

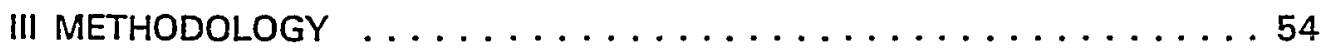

Statement of Hypotheses (and assumptions) . . . . . . . . 56

General Characteristics of the Study Area . . . . . . . . . 57

Conceptual and Operational Model . . . . . . . . . . . 61

Variable Measurement and Data Sources $\ldots \ldots \ldots \ldots \ldots 66$

Summary $\ldots \ldots \ldots \ldots \ldots \ldots \ldots \ldots \ldots \ldots 69 . \ldots \ldots$ 
IV DESCRIPTIVE ANALYSIS OF LANDFILL NEIGHBORHOOD

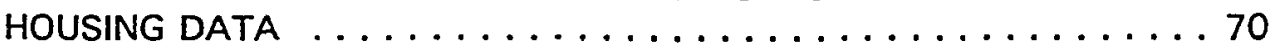

Spatial Distribution of Housing $\ldots \ldots \ldots \ldots \ldots \ldots \ldots 70$

Performance of Housing Market $\ldots \ldots \ldots \ldots \ldots \ldots \ldots 2$

$\checkmark$ FINDINGS OF THE REGRESSION MODELS $\ldots \ldots \ldots \ldots \ldots \ldots .81$

The Regression Models $\ldots \ldots \ldots \ldots \ldots \ldots \ldots \ldots$. 81

Interpretation of Regression Results $\ldots \ldots \ldots \ldots \ldots \ldots \ldots 83$

Pooled Model Results . . . . . . . . . . . . . . . . . 89

Summary $\ldots \ldots \ldots \ldots \ldots \ldots \ldots \ldots \ldots \ldots \ldots$

VI CONCLUSIONS AND RECOMMENDATIONS $\ldots \ldots \ldots \ldots \ldots \ldots 92$

The Significance of this Study . . . . . . . . . . . 92

Policy Implications $\ldots \ldots \ldots \ldots \ldots \ldots \ldots \ldots \ldots$

Suggestions for Future Research $\ldots \ldots \ldots \ldots \ldots \ldots \ldots 98$

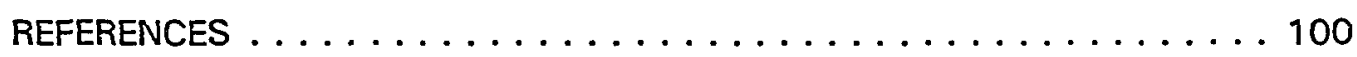

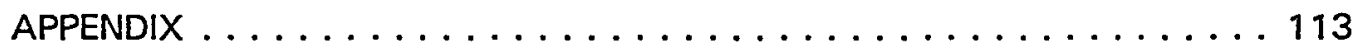




\section{LIST OF TABLES}

TABLES

PAGE

I How is Our Waste Managed? . . . . . . . . . . . . . 28

II Variables for Property Value Impact of Landfills . . . . . . . . . . . 64

III Home Sale by Distance from Landfill $\ldots \ldots \ldots \ldots \ldots \ldots$. . . . . 71

IV Home Sale by Study Period . . . . . . . . . . . . . . 73

$\checkmark$ Home Sale by Age of House $\ldots \ldots \ldots \ldots \ldots \ldots$

VI Home Sale by House Size . . . . . . . . . . . . . . . . 75

VII Comparison of Mean Performance $\ldots \ldots \ldots \ldots \ldots \ldots$

VIII Pearson Correlation matrix $-1971 \ldots \ldots \ldots \ldots \ldots$. . . . . . . 78

IX Pearson Correlation matrix $-1979 \ldots \ldots \ldots \ldots$. . . . . . . . . 79

X Pearson Correlation matrix $-1986 \ldots \ldots \ldots \ldots$. . . . . . 80

XI Regression Results or the Three Periods: Parameter Estimates and Analysis of Variance . . . . . . . . . . . . . . . . . 85 


\section{LIST OF FIGURES}

\section{FIGURE}

PAGE

1. Location of Solid Waste Facilities in the Portland Metropolitan Area . . . 7

2. Location of Lavele Landfill ................... 8

3. Influence of Public Information and Involvement on Perceived Risks ... 43 


\section{CHAPTER I \\ INTRODUCTION \\ THE PROBLEM}

The reason for the existence of local governments has basically been limited to the provision of public goods and services. We have, however, seen the functions of local government grow everyday, as city problems take on new dimensions.

In this paper, the scope of our investigation is narrowed to the controversies surrounding the provision of a special type of public service that necessitates the building of noxious facilities such as landfills and incinerators (Havliceck et al., 1971; Bleich et al., 1991; Nelson, et al., 1992), highways (Burkardt, 1971), mental health (Dear, 1977), nuclear waste (Sun, 1982), hostels for homeless (Burnett and Moon, 1983), and public housing (Rabiega et al., 1984).

A noxious facility such as a landfill provides the essential service of receiving the solid waste we generate. Everybody benefits from the services of this special type of public good. All households are land expected or required to) consume this special type of public service; the reason being that several government regulations mandate collection and disposal of residential and commercial waste with specified equipment, and disposal of same at approved solid waste disposal 
facilities. Illegal dumping of waste carries some penalty in some communities.

Federal and State governments have also enacted laws that aim at guiding and controlling the method of solid waste disposal, and sponsored researches aimed at closing out old dump sites and improving the method of disposal activities.

Since the signing of the National Environmental Policy Act (NEPA) in 1970 there has been unprecedented development of law relating to protection of environment. Two separate Acts, The Freedom of Information Act (which laid down a General rule that all agency data must be available to the publicl and The Administrative Procedure Act (which defines and prescribes procedures for two types of formal agency proceedings: adjudications and rule-making), have increased citizens' awareness of the nature of environmental problems and "public interest" litigations to halt environmental degradation (Mills, 1978; Gladwin, 1980). These suits have forced greater sensitivity in neighborhood consideration of the impact of solid waste facilities located close to or in residential neighborhoods.

What is witnessed today is the Not in My Backyard (NIMBY), Group Against Garbage (GAG), Not On Our Street (NOOS), Citizens Against Virtually Everything (CAVE), Not In My Term Of Office 
(NIMTOO), Not On Planet Earth (NOPE), Citizens Rebelling Against Pollution (CRAP) and Building Absolutely Nothing Anywhere Near Anything (BANANA) syndrome for communities facing the possibility of becoming hosts of solid waste facilities. Landfills (of all types) are perceived as generators of negative effects such as bad odor, disease carried by insects and rodents, noise (from garbage packer trucks transporting the waste and compactors burying the garbage), dust, visual disamenity, and ground water contaminant by leachate. These concerns, host communities claim, affect neighborhood environment and, subsequently, propagate property value decline and loss of property tax (Popper, 1981; Johnson and Pettit 1986; Gamble et al. 1982; Nelson et al. 1992). However, engineers, landfill operators and public officials view limited purpose landfills (that accepts only construction and demolition debris) as those facilities that have lesser impact on the environment.

Most of the older general purpose landfills that accept all kinds of garbage are owned by local and county governments and a good proportion of them are located within metropolitan areas (NSWMA, 1988). This is unfortunate. As a public good the decision to locate a landfills is expected to meet the basic criteria of equity (i.e. locating at optimum) and efficiency (i.e., optimum use). Where these criteria are 
not met, urban residents bear extra costs of garbage hauling, and cost and tax dollars used in building an under used facility. For example, the location of a new regional landfill for Portland, Oregon waste at a distance over 100 miles contributed over 200 percent increase in garbage disposal cost between 1987 and 1992. Even when the equity and efficiency criteria are met some urban residents may still bear additional costs such as decline in property values.

Three problems which local governments have not found the best way to deal with have just been raised: (1) locate at optimum or within the metropolitan boundary and stir up the NIMBY or CRAP syndrome; (2) locate at non-optimum or outside the metropolitan boundary and stir up high costs, and probably illegal disposal within the metropolitan area (Metro 1991); and (3) locate demolition landfills within metropolitan area and general purpose landfills outside. Finding a solution to the first problem will subsequently resolve the other two problems. Some of the ways of resolving the first problem are making monetary compensation to the host community of landfills (Cox and Johnson, 1982) and enhancing neighborhood aesthetics. However, some landfill owners resist compensation; part of the reason being that several studies of the impact of waste facilities on property value show that there is no such impact (Johnson and Pettit, 1986; U.S. EPA, 1975). 
Previous studies of property value impact of landfills have failed to explore equity locational strategies, especially principles of equitable siting process which does not avoid compensation or waste disposal. Moreover, methodologies employed by most of those studies that concluded that there were property value impacts of landfills are inadequate or inferior (Hwang and Rudzitis, 1978). These studies do not also estimate impact to a city block level (Nelson et al. 1992). It has also been pointed out that the methodologies used by these studies failed to estimate the value of those factors not traded on a market (and thus not observable as market prices) which homeowners take into consideration while living close to or away from a landfills (Johnson and Pettit, 1986).

By analyzing a neighborhood housing market before landfill opened, during its operation and after it closed, and employing both linear and non-linear regression equations, the implicit prices of observable and non-observable housing characteristics were estimated in order to determine the premium associated with living close to or away from a landfills. This research studied specifically the premium associated with living in the old Lavele landfill neighborhood in the northeast area of the City of Portland, Oregon (see Figures 1 and 2). 
A literature review of property value theory was carried out first. This was followed by a theoretical explanation of the reasons why some landfills are located within the city limits of most U.S. urban communities. An analysis of those empirical studies that have investigated the impact of landfills on property values were treated. 
FIGURES 1

Location of SW Facilities in the Portland Metropolitan Area

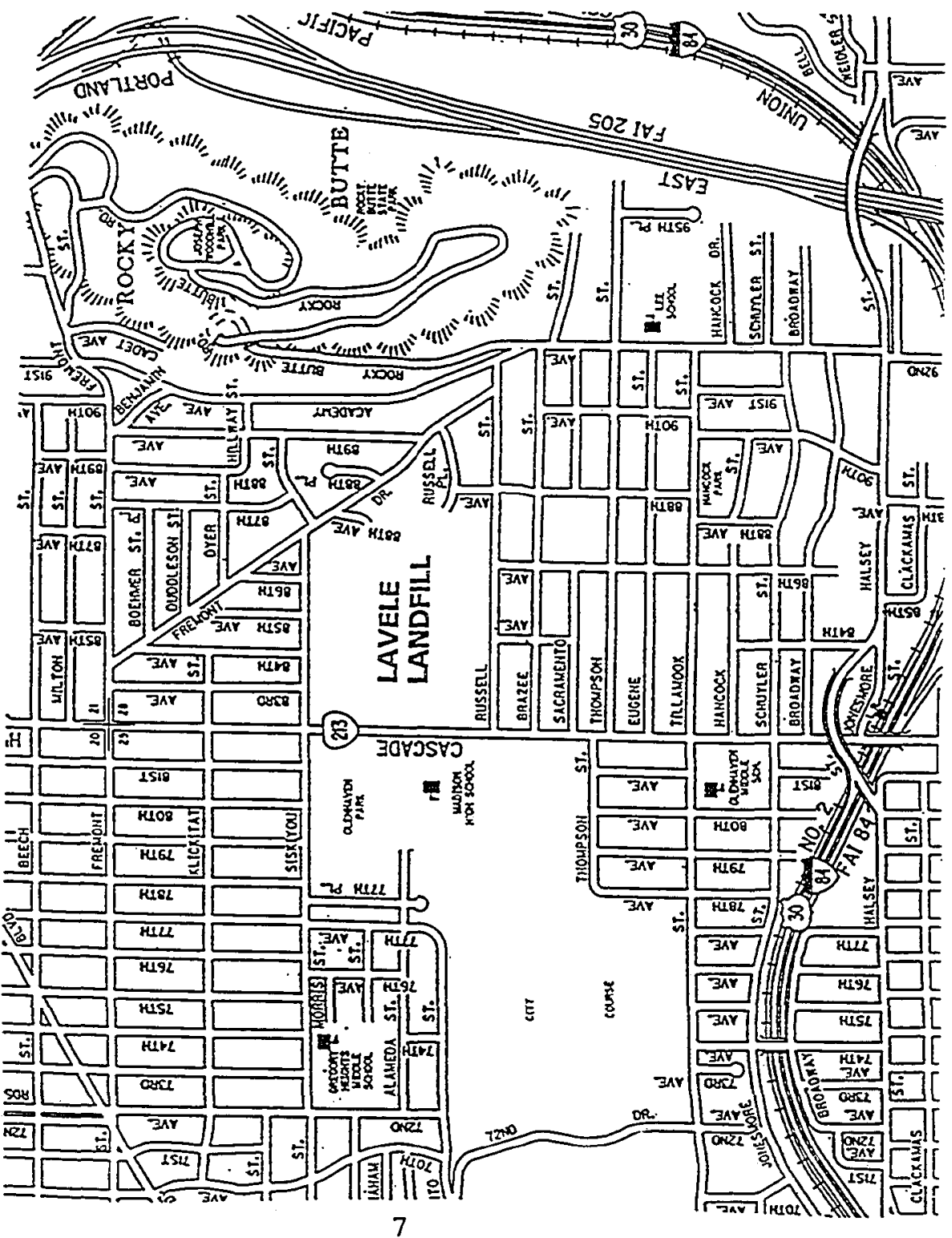


FIGURES 2

Location of Lavele Landfill

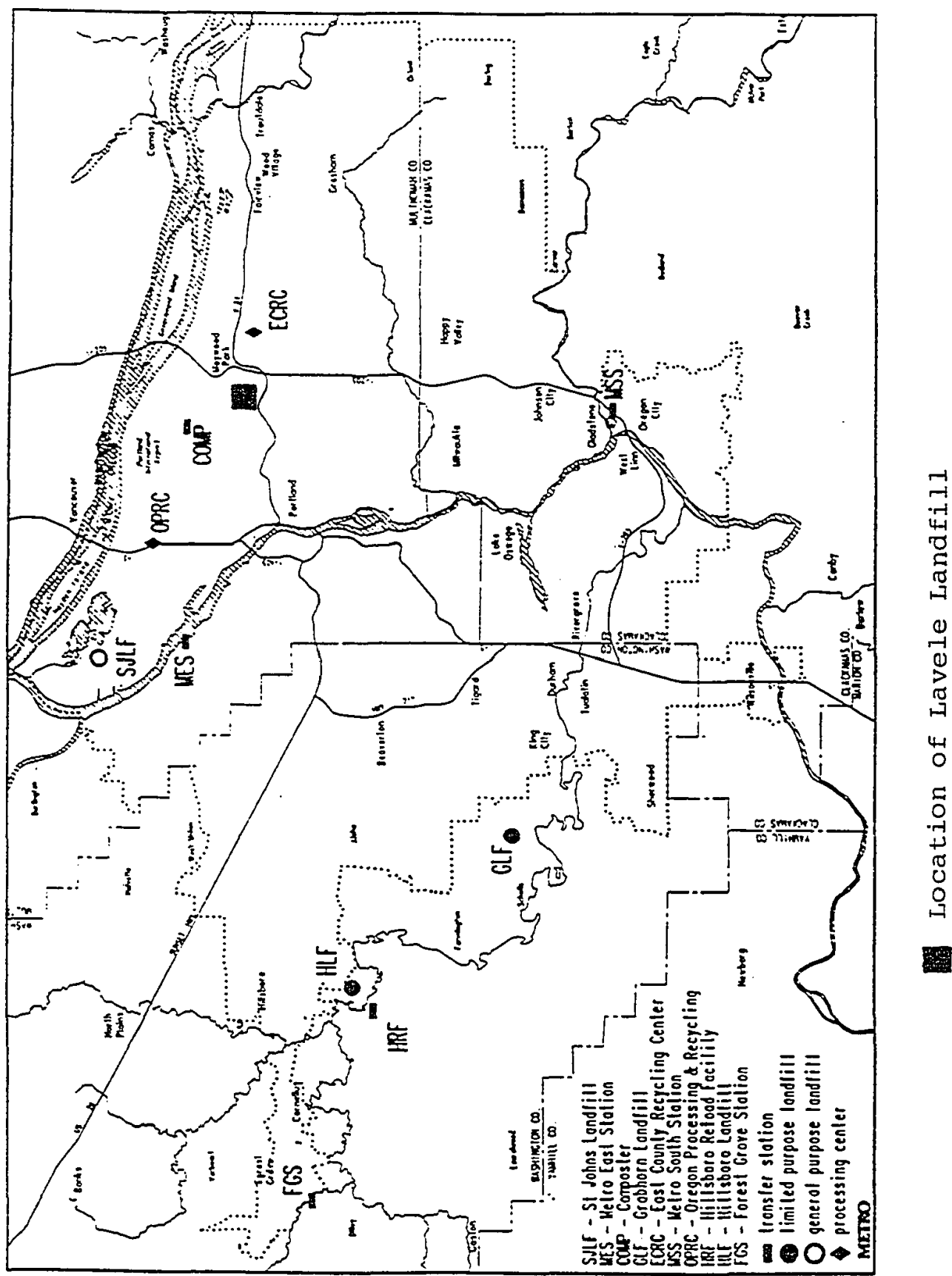




\section{THE OBJECTIVE OF THE STUDY}

The purpose of this study is to determine whether sellers and buyer of residential property in a particular neighborhood perceived a limited purpose landfill in the area as a threat to the value of the area. Determining whether there is a threat is important to neighbors of such facilities, operators of such facilities and local and state governments, because efforts expended arguing on existence of impact can be directed towards settlement. In order to determine how to compensate people affected by a new neighborhood landfill, this study quantified the impact of a landfill as dictated by behavior of sellers and buyers of homes in a neighborhood housing market.

\section{RESEARCH METHODOLOGY}

The study looks at the impact of a solid waste landfill in Portland, Oregon on property values in a high density residential neighborhood using hedonic estimation techniques. In order to segregate and capture perception of risks associated with the operation of landfills a closed landfill was used for the study. Unlike most previous studies that compared a landfill to comparable neighborhoods this study focused on how sellers and buyers of residential properties reacted to the existence and/or operation of a landfill. 
Three multiple regression models were used to analyze the impact of the site on surrounding residential homes before the landfill opened, during operation of the landfill, and after closure of the landfill.

Using the findings of previous studies, those variables that account for residential property value were regressed against sales prices while controlling for distance of homes away from the landfill. Distance of homes away from the landfill is the proxy for perception of the impact of the landfill on residential property in the surrounding area.

\section{SUMMARY OF FINDINGS}

The results of the study confirmed that the operational effects of the Lavele landfill was capitalized into property value. That is to say, the landfill had an impact on property value. During its operation, proximity to the landfill reduced housing pricing $\$ 675$ per city block. After the landfill closed, no significant discount to proximity was detected, suggesting that the external costs of proximity to this landfill were short lived and not permanent and that if landfills are properly regulated home prices will likely increase after closure. 


\section{CHAPTER $\|$}

\section{REVIEW OF LITERATURE: THE THEORETICAL BASIS FOR LANDFILL LOCATION AND HOUSING ATTRIBUTES}

The scope of this chapter is to examine the different environmental factors which different studies have shown to affect residential property positively and negatively. Our goal here is to explore the findings of various research on property value and landfill location in order to lay a foundation and theoretical basis for identifying those factors that will be useful in establishing the connections between property value and landfill operation.

The exploration is in three parts. The first part is on literature which deal with factors that account for variations in property value. The second part concentrates on literature which treated those factors that influenced the siting of landfills in our communities. The third part identifies previous empirical studies of landfill impact on property value.

\section{THE THEORETICAL FOUNDATIONS OF PROPERTY VALUE}

Our aim in this section is to explore the theoretical foundations of property value in order to determine those utility generating factors not necessarily traded in the market but which homeowners take into consideration while living close to or away from landfills. 
This research identified two schools of thought that have contributed much to the study of variables that account for variations in property value among urban neighborhoods. The first school is the classical urban land use market theorists (von Thunen, 1966; Alonso, 1964; Muth, 1969; Waldo, 1974) and the second school is the contemporary professional property appraisers/assessors (Schmutz, 1944; Vaughan, 1984; Rutledge, 1986). The reader should note that the latter school has benefitted more from the work of the former.

In determining the value of a property, appraisers and assessors have always used three standardized approaches; 1) market; 2) income; and 3) cost. These approaches employ similar or same variables. As pointed out by Goulet (1979) and Rutledge (1986) an appraiser can use one or a combination of two or all of the three approaches in an appraisal of one property.

The market approach rests on the premise that investor (or home buyer) behavior produces a range of prices within which a reasonably accurate value estimate can be made (Schmutz, 1944; Kahn et al., 1963; Vaughan, 1984). The market approach is used mostly for residential property - the type with which this research is concerned. This approach is one in which the property under appraisal is valued on the basis of sales data of comparable properties which have recently 
been sold or offers to buy have recently been made. Adjustments are made for dissimilarities in date of sale, size of lot and building, improvements, financing methods, and location in order to arrive at market value.

The second approach is the income method which rests on the premise that the value of real property is equal to the capitalized value of its future cash benefits. This approach, used mostly for income producing properties, restates market value by converting future benefits on losses of property ownership into an expression of present worth. This implies projections for increased or decreased cash flow and derivation of a market rate of return used to estimate future cash benefit or loss of a property.

The third appraisal method is the cost approach. This approach is based on the premise that a property should never be valued at a price above its replacement cost. The procedure requires an estimation of the reduction cost of an identical (or hypothetical) structure, and estimation and deduction of accrued depreciation. Both estimates require use of a variety of complicated indices for the structure and accrued depreciations. Three classes of depreciation that influence property value are physical deterioration (due to structural defects), functional obsolescence (due to effect of inadequate services), and economic 
obsolescence (due mostly to exogenous effects to the structure such as noise and inadequate public services).

From the foregoing analysis, we can say that the variables taken into account by the assessors and appraisers are those indirectly reflecting the condition of the property being valued and its environment. Although these approaches require use of extensive data, time and adjustments, a greater portion of the assessors judgment is purely subjective. Take, for example, the case of the cost approach. To the extent that adjustments for physical deterioration can be easily estimated, adjustments for economic and functional obsolescence may be incorrectly or poorly conceived. The proximity of a factory located close to a residential property may be translated into a high utility by the factory employee who intends to buy a property in the neighborhood, whereas the proximity may translate into a disamenity for someone else.

According to an interview with the Assessor for Multnomah County, Oregon, the market and cost approaches are still popular. However, there is an increasing demand to apply a statistical approach which takes into account relevant exogenous variables directly reflecting the condition of a property and its environment. The new "statistical appraisal equations" method borrows a lot from the classical land use 
market theorists. The rest of our analysis of the theory of property value will dwell more on the contribution made by the classical land use market theorists.

a) Accessibility Attributes of Property Value:

The classical theory of property value which originated in the work of von Thunen traced the variations of agricultural land rents to differences in fertility and location in a hypothetically isolated farm community (von Thunen, 1966). Twentieth century urban and regional economists have applied similar models in their explanation of urban land value. Alonso is one of the neo-classical theorists of urban land value who used von Thunen's work in shedding light on the reasons for variations in both rent and property value within a city.

The central business district (CBD) of the city, Alonso (1964) argues, has all activities, and roads in the city lead to it. Competition of different types of uses, as a result of the convenience of the CBD, drives rental charges higher than in other parts of the city. While land on which to build is plentiful, land with accessibility to the CBD is scarce (Alonso, 1964; Goodall, 1974; Heilbrun, 1981).

In further analysis, .neo-classical theorists point out that at the CBD transportation cost is zero, rent per square foot is higher, and a movement outside the CBD implies a substitution of transportation cost 
for more consumption of space. This phenomenon generates a site rent gradient for the city that has its peak at the city center and declines as we move away from the center.

Although the city center may be the area of highest property value, the expansion of the city, and subsequent development of suburbs and multi-nuclei centers of activities such as shopping centers have added more peaks to the site rent gradient of the city. The empirical work of Li and Brown (1980) suggests that proximity to certain non-residential land use such as school, recreation areas, river, expressway interchange affects property value by having a positive value for accessibility.

Proximity to employment center reduces the opportunity cost rate of commuting time. The value of time saved is one of the most salient components of the highway user's benefit for which county assessors show concern while evaluating properties close to areas where improvements in transportation systems are occurring (Waldo, 1974).

\section{b) Physical Attributes of Property Value:}

Alternative explanations for changes in property values have been addressed from the point of view of physical attributes. In a theoretical treatment of the competitive model of the housing market, Olsen (1969) 
portrayed housing as a physical commodity with attributes, each unit yielding some "housing service." The consumer realizes a certain level of housing service by satisfaction trading off or combining housing attributes.

The empirical work of Rosen (1974) on implicit market analysis of hedonic price determination, which borrows heavily from Olsen's housing service approach, shows that most consumers value some housing attributes over others. Consumers in a typical residential neighborhood value floor space and yard space (Rosen, 1974; Brueckner and Colwell, 1983).

The work of Brueckner and Colwell (1983) show also that floor and yard space per house are greater farther from the CBD. Now, in order for the consumer to maximize utility for a property located close to a noxious facility, the marginal rate of substitution between housing attributes must equal the marginal value of the property. Recalling that consumer's choice of property is dependent also on other factors (such as accessibility attributes), the substitution case is based on a wide variety of variables. As a result, in any empirical investigation of the factors that lower or increase property value, there will be either a "many equation system" or an equation comprised of many subequations. By performing comparative calculations using varied equation 
systems, the effect of one variable, given the existence of a different but comparable variable, can be determined.

c) Neighborhood Attributes of Property Value:

The impact of neighborhood attributes on property value can best be understood by defining and relating them to the structure of residential property value. The attributes derive their definitions from the vital role they play in a neighborhood. Before proceeding to define the attributes we have to answer a question which is proper at this juncture: what is a neighborhood?

The definition of a neighborhood varies depending on the perspectives adopted by its residents. The perspectives include geographic, social (Coleman, 1978; Downs, 1981) and economic (Downs, 1981). That is to say, the attributes of a neighborhood can be grouped into geographic, social and economic variables. A housing market located, say, in a harbor or landfill area could adopt the names "harbor neighborhood" or "name of landfill". The personal relationships among residents are reinforced by harbor activities forming invisible (Downs, 1981) and visible networks that define the neighborhood. These tangible and intangible networks are vital to the "harbor 
neighborhood" real estate market as well as to the businesses, streets, and even the garbage collection system in the area.

This approach to defining a neighborhood broadens the geographic and social attributes to include the economic perspective of a neighborhood. A more comprehensive view of defining a neighborhood may include the political perspective; however, the political attributes develop in the later life of a neighborhood, either due to the need to preserve or enhance the growth of the resources in the neighborhood.

To the residents of any community, the most crucial resources in the neighborhood are their property, socioeconomic infrastructure and businesses that provide employment and revenue. (Downs, 1981; Coleman, 1978). The socioeconomic resources include schools and parks. Schools have been empirically investigated and shown to exert some amenity/disamenity capitalized in residential property value (Kain and Quigley, 1970; Harrison and Rubenfield, 1978; Li and Brown, 1980). These studies employed different variables to determine the quality of schools. The results of these studies show that the proxy measures which include racial composition, achievement levels, and expenditures per pupil were found to indicate that home buyers are concerned about the quality of education. Thus, homes in those 
neighborhoods with high quality schools would actually compete with each other as alternatives to buyers. Theoretically sellers should attempt to capitalize the quality of education in property value, unless the sellers fail to recognize the quality of education in the neighborhood school.

The link between property and neighborhood attributes have economic as well as social facets. As Aaron (1985) put it:

\begin{abstract}
"When a homeowner or renter chooses a house or apartment he purchases not only housing services, but also a wide range of goods and services - public schools, stores, parks, public transportation, neighbors, and other amenities. Though they cost him nothing beyond the price of housing and attendant property taxes, his satisfaction - indeed, his welfare - depends on these commodities as much as on housing. He does not express in marketplace his demand for housing but for the entire package. Statistics on housing expenditures therefore really measure the value placed by residents on housing and residential services."
\end{abstract}

These residential services are what makes a neighborhood tick.

They are also fragile, hence, there is some susceptibility to future decline (Downs, 1981). There are some key economic and social factors that increase the susceptibility to future decline of the neighborhood attributes as pointed out by Downs (1981). These factors include:

1. inability or failure to rehabilitate properties due to absentee owners or house too expensive to maintain; 
2. withdrawal of a key local institution;

3. land use changes, such as the building of an expressway;

4. immigration of households different from the average in the area--by income, ethnicity, or socioeconomic status;

5. transition to lower income occupancy in adjacent or nearby neighborhood;

6. large increases in property taxes that force owners to put their houses on the market ail at once and thereby depress property values; and

7. declining or inadequate public service, such as infrequent garbage collection, or poor quality public schools.

The factors listed above (except no.3), have one common denominator, money. Lack of money (household income) causes property owners to devote less money for improvement purposes. The additional impact of inflation helps to force some property owners out of a housing market, or out of some locations in the city. When key local institutions close their doors or relocate, unemployment increases, tax revenue goes down, and the proportion of income devoted to home improvement declines. Lack of home maintenance by one homeowner causes his neighbors to worry about negative externalities that appear 
as a result of little or no improvement. Lack of and limited public money for rehabilitation loans or grants make the matter worse.

According to economists' externalities violate a condition for the optimality of market equilibrium (Piggou, 1920; Mishan, 1974; Siebert, 1981). In a neighborhood housing market, the production and sale of housing involves market agreements between the seller and buyer determined on the basis of neighborhood attributes including externalities. The equilibrium set of housing prices that emerge from such a system is the result of the combined economic behavior patterns of these two groups of individuals who play in the neighborhood housing market. Any change, say an alteration in the behavior of one or more persons, is able in principle to change the equilibrium set of prices, thereby affecting the utility levels of all persons and the output of housing attributes (see Mishan, 1974). That is to say, if a homeowner's production of housing improvement is low compared to others, the neighborhood housing market will no longer be in equilibrium.

Another neighborhood attribute that disturbs the equilibrium set of housing prices is zoning. The zoning system for an urban location has been shown to have impacts on land and property values. Any attempt to differentiate parts of a metropolitan area for purposes of growth and development must come from the planning and zoning system 
(Mandelker,1974; Sternlieb and Sagalyn 1973). As Ohls et al. (1974) pointed out zoning alters the land markets, making substitution between markets impossible, and thus result in land use markets which alter prices, at the expense of one market to other types of land uses. In another study Maser et al. (1977) concluded that there was no evidence that zoning affected real estate value in Monroe County, New York. However, in another study, Jud (1980) stated that methodological errors in sample design and model specification cloud the results of the study of Maser et al. By using a hedonic housing price model to investigate the effect of zoning on single family residential property values, Jud (1980) showed that zoning-related attributes of a house are the most significant determinants of residential property values.

The location of solid waste facilities or other noxious facilities within or close to residential housing is a result of mixed or flexible zoning. As stated earlier, there have been many claims that the location of such facilities, within a residential neighborhood, exert externalities on housing in close proximity. Our task in this research, of course, is to prove or disprove the claim. Before introducing the reader to a review of the empirical studies of landfills impact on property value, we will first discuss the locational strategies of landfills, and especially the locational factors that contribute to continued siting of landfills within 
the growth boundaries of our urban communities. The essence of this detour is to give the reader a better perspective of the link between the theories of property value, landfill location and landfill impact redistribution and compensation. 


\section{THEORETICAL FOUNDATIONS OF LANDFILL SITING AND IMPACT}

According to Johnson and Pettit (1986) the property impact of landfills will depend largely on the facility's location and the residents' perception of environmental risks and their general attitude towards solid waste facilities. If the foregoing claim is true, one may want to know where landfills are located and why they are located where they were or are now. The topic of this section is derived from the answer to the questions we have just posed.

The decision regarding the location of public facilities are different from those of private sector facilities. For the latter, the choice of location is based on demand function which lays emphasis on and tries to balance equity (consumers choice functions obtained from revealed preference affected by distance) with efficiency (profit maximization). Within the equity context the emphasis is on balancing distance of the location to all possible consumers (Berry 1962; Golledge et al., 1966; Reilly 1931; Gosh and McLafferty, 1982) and posting competitive prices, better quality goods and a large assortment (Gosh and McLafferty 1982; Huff 1981). The efficiency, on the other hand, is measured by the profit of the firm (Gosh and McLafferty, 1982). These measurement parameters do not apply in the location decisions for public facilities, especially noxious facilities such as landfills. 
The location decision for a public facility is based on criteria which differ among facilities, whether noxious or not. The issue just raised can be better understood by examining in detail how the services of public facilities are consumed.

Spatial interaction theory differentiates services of public facilities that are delivered from travelled-for services (Lea, 1979). For example, emergency services are delivered services whereas the services of landfills or public library are not delivered. The level of consumption for delivered services such as emergency services influences the location from which the service is provided. In addition, consumers do not have to bear the cost or inconvenience of travel associated with service provision, but through service quality, travelled and distance affects consumption (Thisse and Zoller, 1983).

In the case of travelled-for services such as final disposal of waste at landfill (landfilling) and public library, the same level of service is made available at costs varying with the consumer location (Thisse and Zoller, 1983). The level of consumption may be affected by distance of consumers living at different locations from the facilities. The consumers of landfill services include franchised haulers and citizens who self-haul their waste to the landfill. 
In the past century and up to the first half of this century, landfills (or dumps as they were called) were located mostly within the city or metropolitan boundary with little or no opposition partly because self hauling was predominant, hence the use of or consumption of the services of such facilities is affected by distance to the customers. Personally, host neighbors of these facilities traded short self-hauling distance with environmental quality of their neighborhood.

During the 1910 s and 1920 s cities introduced garbage collection trucks and city-wide collection, and engineers developed the concept of modern landfilling as a method for reclaiming wetlands near cities with layers of garbage, ash and dirt (Melosi 1981). These two factors encouraged the location of landfills within the urban environment of most cities. Infact the continued location of landfills within the metropolitan area was also because local governments were mostly responsible for collection and disposal of solid wastes from homes and, to a limited extent, from commercial and industrial establishments. Locating within their boundaries means keeping down costs associated with disposal of municipal solid wastes.

The Solid Waste Disposal Act of 1965, the Resource Recovery Act of 1970 and subsequent amendments and related Acts, which contain federal government's policy toward solid waste has clearly 
revealed the environmental risks associated with solid waste facilities. The other indirect impacts of the Acts are the increase in environmentalsensitive publications by various interest groups and passage of more federal and state legislation that put very stringent measures on landfills design and management. On the other hand, host neighbors who were no longer enjoying the benefits of short self-hauling distance started to have a different view of landfills. The risk and resentment of open dumps, at least in metropolitan areas, and the need to protect human health and the environment prompted federal and state governments to start closing most of the dumps in the country (Mills, 1978).

Despite the concerns being raised by federal and state governments and environmental groups around the country, the choice of waste disposal continue to be landfills as shown in Table 1. Up to 1992, about 69 percent of waste generated in the United States of America were disposed of at landfills, unlike the other 11 and 19 percents of the wastes that were managed through recycling and wasteto-energy respectively. 
TABLE 1

HOW IS OUR WASTE MANAGED?

(millions of tons per year)

\begin{tabular}{|c|c|c|c|c|c|c|c|c||}
\hline & \multicolumn{2}{|c|}{1960} & \multicolumn{2}{c|}{1970} & \multicolumn{2}{c|}{1980} & \multicolumn{2}{c|}{1992} \\
\cline { 2 - 9 } & volume & $\%$ & vol. & $\%$ & vol. & $\%$ & vol. & $\%$ \\
\hline Landfills/Other & 31.7 & 93 & $\begin{array}{c}112 . \\
1\end{array}$ & 93 & 124.6 & 76 & 119.6 & 69 \\
\hline Recycling & 5.8 & 7 & 8.0 & 7 & 17.7 & 11 & 19.5 & 11 \\
\hline $\begin{array}{c}\text { Waste-to- } \\
\text { Energy }\end{array}$ & - & - & 0.4 & 1 & 20.3 & 13 & 33.4 & 19 \\
\hline \hline Total & 87.5 & $\begin{array}{c}10 \\
0\end{array}$ & $\begin{array}{c}120 . \\
5\end{array}$ & $\begin{array}{c}10 \\
0\end{array}$ & 162.6 & $\begin{array}{c}10 \\
0\end{array}$ & 172.5 & $\begin{array}{c}10 \\
0\end{array}$ \\
\hline
\end{tabular}

Source: EPA. Report to Congress. Solid waste Disposal in the United States, Washington, D.C., 1988; IRR Facility survey. July, 1989.

Popper (1981) in his well-cited article, "Siting LULUs" (Locally Unwanted Land Uses), explained the spatial configuration of noxious facilities locations and shaded more light on the four land-use strategies used successfully by the public sector in their location decisions for noxious facilities including landfills. These strategies are summarized as:

1. deliberate or natural concentration of noxious facilities in underdeveloped area of a city;

2. facilities are dispersed or spread out, as in the case of fairshare of public housing in Dayton, Ohio; 
3. deliberate siting of noxious facilities haphazardly (or through a randomization process); and

4. through on-site mitigation strategy, public officials try to mitigate impacts of the facility, thereby reducing the social cost and increasing the social benefit of the project to the community.

Several analyses show also that there are some factors (or variables) that make the four strategies work best. These factors are natural or human-made features such as home-rule or neighborhood sentiment, exclusionary zoning, persuasion (through public hearing or debate, and expert opinion), and economic incentives (through grant, cash payment, improvement in public service, or taxation device) (Popper, 1981; Seley, 1983; Dear, 1992). To the extent that these factors make it possible to realize the objectives of the public official, they represent tools that make it possible to locate noxious facilities in minority and politically underdeveloped communities within the U.S. metropolitan boundaries (Gittel, 1980; Popper, 1981).

As the case may be, some of these tools are becoming less effective due to the current multi-faceted positions taken by NIMBY. As pointed out by Heiman (1990), there exist, on one hand, some environmental groups such as Conservation Foundation and National Wildlife Federation who agree (with public officials) that waste facilities are needed, although there are undesirable neighbors, hence mitigation, 
negotiation and compensation are necessary. On the other hand, there are other grassroots environmental populism demanding that government and industry must demonstrate successful waste reduction and recycling efforts before any new negotiation for siting could be initiated. What we are now facing is shift from "Not in My Backyard" to "Not in Anybody's Backyard". We are now witnessing new environmentalists applying new opposition strategies and tactics such as: a) letter-writing campaigns to the facility owner, local politicians, and the media; b) lobbying elected officials; c) vigilante action; d) demonstrations; and e) effective citizen participation through effective presentations in the zoning variance process (Dear 1992).

To recapitulate, we have shown that the strategies used by local governments and landfill sponsors to locate landfills has been effectively challenged by environmental groups and landfill neighbors. The later group demand that governments must come up with better locational strategies that recognize the burden associated with living ciose to a landfill, and take into account the distribution of the burden to everyone in the society that uses the services of these facilities. 


\section{LANDFILL LOCATION AND IMPACT MITIGATION}

Now, let us explore the strategies that public and private organizations have used recently to locate facilities such as landfills.

Those public officials who have faith in the liberal planning tradition are seriously engaged in promoting participatory democracy in which host neighborhoods and facility sponsors are brought to the negotiation table during the siting process. Some negotiations resulting from this initiative focuse on educating everyone on the potential risks and methods of minimizing the potential burdens of the facility (Metropolitan Service District 1987).

Recently the City of New York developed fair share criteria (rules) for siting municipal facilities, which was required by a new city charter adopted by referendum in Autumn 1989. The inclusion of the fair siting criteria in the charter was as a result of testimonies of community representatives before the Charter Review Commission that their neighborhoods were burdened with unfair shares of objectionable facilities. Hence, the new charter required the Mayor to propose new guidelines for equitable distribution of the burdens and benefits of city facilities. The charter's intent is to distribute among communities the burden and benefits associated with city facilities, including landfills, consistent with community needs for services and efficient and cost- 
effective delivery of services, and with due regard for social and economic impacts of such facilities upon the areas surrounding the sites (Weisberg, 1993). The criteria would serve as a set of planning guidelines in the city's comprehensive land use planning and review procedures. For solid waste facilities, the criteria recognizes the need to concentrate them in industrially zoned areas, but requires the degree of concentration to be weighed against considerations for need, cost and service efficiency (Weisberg, 1993). The American Planning Association honored the New York's fair share siting guidelines as an innovative planning tool for conflict resolution before there were actually tested.

The city's fair share criteria has been thwarted by five interrelated obstacles summarized below from Rose's (1993) study:

a) differing opinions on the definition of fairness;

b) the process of balancing equity and cost-effectiveness through statistical calculation of localized need, provokes more conflicts than it solves;

c) the use of 59 community districts as the geographic level of equity evaluation for facility siting is meaningless because these districts differ by land area, population density and community character;

d) the relative burdens of the different kinds of facilities are not factored into the fair share approach; and 
e) no clear provisions (such as compensation or incentives) for implementing siting plans developed through the fair share process.

Rose also pointed out that the criteria are a "dubious proposition that runs counter to the basic principle of good planning" because they negate the basic principles of zoning as a fundamental planning tool for isolating the burden of noxious facilities from the general population. In light of this reasoning, Rose discourages local governments form adhering to the fair share approach, and encourages the concentration of public facilities with business and institutions which offer each other different forms of locational benefits. The problem with Rose's proposition is that his views were derived from careful analysis of the locational problems associated with the siting of public facilities such as shelter for the homeless and homes for mental patients. The characteristic differences between shelters and public facilities such as landfill limits the support for his proposition. Besides, the use of zoning to concentrate similar facilities or to site landfills may not be possible because communities and NIMBY advocates can mobilize to prevent such initiatives.

The use of the same equity and efficiency criteria for locating certain facilities may not be applicable to noxious facilities such as landfills. The failure of the City of New York's highly popularized Fair 
Share criteria for siting of public facilities clearly demonstrates the urgent need for a new locational strategy. It must be pointed out that the New York guidelines avoid any form of compensation strategy. It must also be pointed out that the major strategic tool for implementing the New York guidelines is zoning variance. The effectiveness of zoning or zoning variance in land use planning is limited for making location decisions for landfills because of the multi-faceted nature of NIMBY sentiments, pointed out earlier, and the insistence of community and environmental groups that governments should come up with acceptable equity locational strategy or strategies.

As has been shown, local planners, public officials and facility owners have come to grips with reality. Opposition to landfill siting or location is not necessarily a site specific location problem. It is rather an opposition to unfair distribution of the burdens associated with the provision of noxious facilities like landfills. What are these burdens? As has been indicated earlier, neighbors of landfills and noxious facilities claim that because of the proximity their property value are affected negatively, and they run the risk of health problems resulting from the technical risks associated with these facilities.

Several studies of locational conflict involving noxious facilities stress the need for mediation/negotiation and compensation (Dear, 
1992; Forester, 1987). Dear states that considerations of neighborhood complaints about noxious facility impacts can really result in valuable improvements to proposed and existing facilities. Hence, he encourages planners to "choose between two alternative approaches: 1) collaboration, implying cooperation between operator and host community; 2) autonomy, acting independently of the host community." The Massachusetts Hazardous Waste Facility Act of 1980 did exactly this by establishing a new siting process that addresses the "acceptance" of such facilities by host communities. As pointed out by Wetmore (1980), the objectives of those who drafted the Act were:

1) make those facilities attractive to potential host communities and their neighbors, thereby encouraging the siting of facilities with as few delays as possible;

2) increase public confidence in the safe operation of hazardous waste facilities;

3) effectively utilize the private sector's existing marketing, management, and development expertise; and

4) make the most efficient and effective use of public resources presently being invested in permitting, licensing, environmental analysis, community assistance, and development.

As Dear (1992), Michaels (1990) and Wetmore (1980) point out, those mediation/negotiations that focus on educating the society or facility neighbors on the risk associated with the facility and how the 
risks would be minimized, are more likely to prevent the adversarial atmosphere present in most siting efforts and operation.

Metro, a regional government planning agency in Portland, Oregon, was mandated by a state law (Senate Bill 626) to establish its first solid waste facility neighborhood enhancement program land trust fund) in August 1986 . The program is funded by a 50 -cent per ton surcharge on disposal fee (directed by the state law), for the purpose of funding projects that improve the image of a solid waste facility neighborhood. Some private companies such as Chambers Development Company, Inc, guaranteed Charles City and County, Virginia, a host fee of at least $\$ 1.14$ million per year to open a new landfill, free garbage disposal to the county, and pays a county hired engineer to inspect the landfill (Walls and Marcus, 1993).

The mediation approach adopted in the Metro program (neighborhood enhancement) and Charles City/County program (annual host fees and free disposal) place little or no emphasis on how the risks associated with landfill operation would be minimized. Both programs emphasize and implement actions that would likely offset potential reduction in property value in the host neighborhood.

By relying on higher disposal fees to finance their compensation packages, these programs assume that equity redistribution of landfill 
burden is being achieved. The issues that needs to be addressed at this juncture are whether the current methods of compensation described earlier addresses unfair redistribution of landfill burden and whether compensation is limited or goes beyond the impacted area. An argument could be made that the programs are not "robbing Peter to pay Paul," rather those responsible for creating landfill impact should be responsible for paying the cost associated with removing the impact.

On the other hand, the willingness of facility owners to propose compensation at the announcement of a new landfill project raises questions about the principles of such progressive compensation approach, and whether the process will lead to equilibrium of compensation.

The premise of the existing compensation programs is flawed. The inadequacy of measuring tools imply that all the consequences of landfill location cannot be fully established. The implications are:

1) the compensation is not based on documented evidence of burden, such as decline in property value;

2) citizens may be over taxed (through high disposal fee), thus leading to regressive overcompensation;

3) level of compensation for host neighborhoods of landfills may be inadequate;

4) compensation may not be targeted to impacted groups; and 
5) they do not exhibit evidence of equity distribution of landfill burden.

The four foregoing issues are interrelated, hence the solution to the first issue will equally solve the other four issues. That is to say, establishing the existence and amount of burden associated with living close to a landfill will provide the yardstick for determining how to redistribute landfill burden equally or fairly and thus the tools for: a) determining the level of compensation for host neighbors; and b) resolving landfill locational conflict.

Given the foregoing analysis, this study aims to establish the existence and amount of landfill burden on neighbors, even though several studies show that noxious facilities, including landfills, have no impact on property value: Dear (1977) - Mental Health Facilities; Wolpert (1978), Dolan and Wolpert (1982), - Group-Home Residences; Nourse (1963), Schafer (1972), Rabiega, et al (1984), - Public Housing Projects; U.S. EPA (1972, 1975), Metro (1981), Gamble et al. (1982), Palm Beach County Solid Waste Authority (1986), Bleich et al. (1991) Landfills. Another objective of this study is to provide guidance for demarcating the boundary of the impacted groups or neighborhoods.

The procedure employed in this study for determining the existence and amount of burden resulting from the presence of landfills 
is based upon the theory of hedonic prices. The theory of hedonic pricing provides conceptual basis for estimating the demand functions of certain goods such as urban amenities (pure clean air, pure water) not traded in explicit market. The demand functions developed by Rosen (1974) employ housing characteristics that includes urban and neighborhood attributes to estimate prices of explicit housing characteristics and household willingness to demand or pay for a housing trait. As described later in the methodological chapter, the hedonic pricing procedure provides the tools for measuring the amount of landfill burden which could be used as a guide for developing compensation programs and the target groups.

Our goal in this study is to design a methodological framework that can control for neighborhood attributes while using a covariant application of hedonic modelling or a covariant regression equation to determine respectively the price of landfills disamenities or the implicit prices of all variables that contribute to property value increase or decline. Before going into more discussion of the hedonic procedure later in the methodology chapter (III) we will first review previous studies of landfill impact to determine the weaknesses in the methodologies the studies employed. 


\section{PREVIOUS STUDIES OF LANDFILL IMPACT}

Not a great deal of empirical work has been completed on the subject of landfills impact on property value. In a study of the impacts of solid waste disposal facilities by the Metropolitan Council of the Twin Cities Area (1982), the potential environmental impacts and mitigation measures were enumerated. The environmental impacts include surface water and ground water pollution, air pollution from trucks, dust and gases from truck traffic, noise and litter, and loss of vegetation or wildlife.

Some of the mitigation measures include 1) installing of liners under landfill sites to reduce risk of leachate seepage into the groundwater, 2) installing of leachate collection system, 3) controlling disposal of hazardous waste, 4) oiling or watering access roads to disposal facilities, 5) building buffer around the landfills area, 6) routing traffic through less densely populated areas, 7) limiting operation to certain times of the day, and 8) installing litter control around the site. (Metropolitan Council of the Twin Cities Area, 1982; Metropolitan Service District 1981; GRCDA, 1988).

Governmental Refuse Collection and Disposal Association GRCDA (1988), one of the leading solid waste associations in the U.S.A., argues that stringent measures introduced by federal and state 
environmental agencies have reduced the risks usually associated with solid waste disposal facilities. GRCDA claims the NIMBY syndrome appears not to be related to technical failures but rather to

"....the present weaknesses of the public and their attitude about garbage. They were raised from childhood to consider trash an unpleasant product of human life....carrying out the garbage was an assignment which everyone hated..... The garbage man was considered very low on the social standing totem pole in a community.... Mentally, the public, for generations, has been raised to not like trash....consequently we have a major challenge to overcome the public's mental image of solid waste...." (pp 1-2)

It would seem that the greater portion of the concerns associated with solid waste facilities are psychological and based mostly on perception of their operations. In a study of Potential External Effects at Selected Prototypical Solid Waste Facilities prepared for the Metropolitan Service District (1987) by ECO Northwest, the analysis of citizens' perceptions has been carried one step father.

In the study ECO Northwest distinguishes the risk associated with solid waste facilities into technical risk and perceived risk. Technical risk is defined as "the best estimate of expected values as determined by technical experts." Perceived risk is defined as the derivative of how people assess risk for themselves, which may depend in a large or small way on how experts assess technical risk associated with operations. 
ECO Northwest went on to state that part of the mitigative measures that will reduce perceived risk includes communications with citizens.

Getting the citizens involved in the solid waste management policy-making process reduces their fear of the impact of solid waste facilities because the citizens become more acquainted with the type of stringent measures being taken to keep technical risk at a minimum level. In concept, the relationship between public information and perceived risk is translated into expected value or the value of the technical risks should they occur. 


\section{FIGURE 3}

Influence of Public Information and Involvement on Perceived Risks

Technical Risk

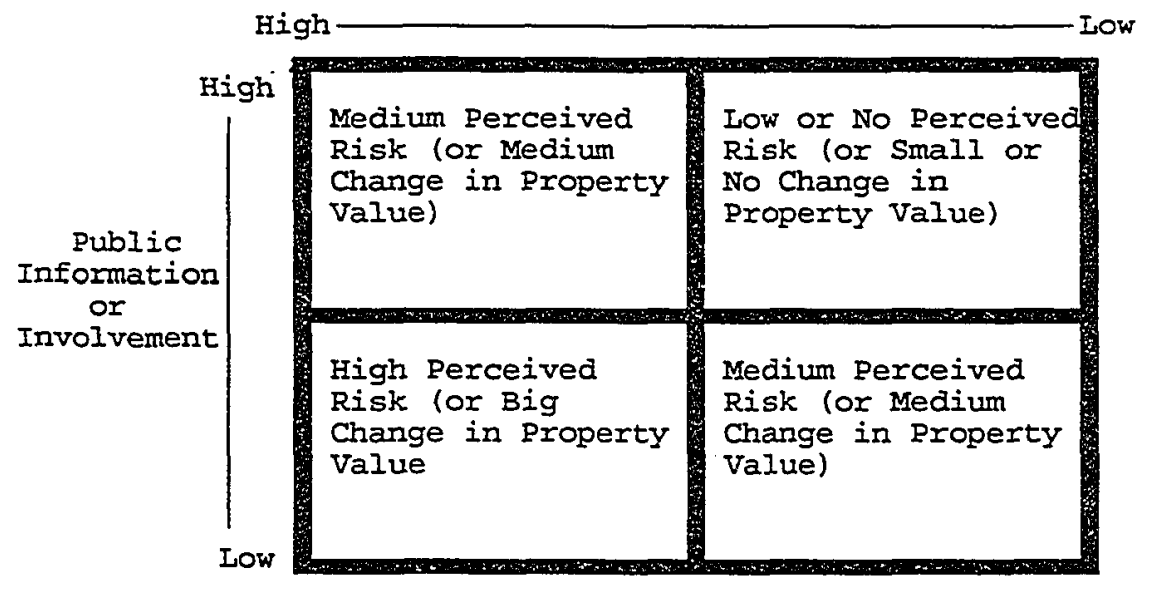

As shown in Figure 3, high public information on the operations of a highly technical risk facility (like Nuclear Plant) will yield medium perceived risk or change in property value. As shown also in Figure 3, high public information regarding day to day operations in a low technical risk facility (like Landfills) will pose little or no perceived risk for property value.

It would seem that a superficial approach to determining the probability of a solid waste facility impact is to gauge a facility site against type of waste accepted or the mitigation measures (which include both the extent of public information or involvement and 
measures taken to minimize technical-risk). Mitigation is a mechanism to reduce, minimize or eliminate predictable, measurable negative impacts, and this means that it is a mechanism to provide support for property values (Metropolitan Service District, 1986; Metropolitan Council of the Twin Cities Area, 1982).

The State of Oregon requirements for mitigation measures differ by landfill mainly because of the type of waste accepted or buried at the site. Until October 9, 1993, the level of mitigation measures required of those landfills that receive dry waste (or waste that does not include food or putricibles) and referred to as "limited purpose landfills" was much lower (Oregon Department of Environmental Quality, 1993). Unlike the limited purpose landfills, those facilities that receive all kinds of waste and generally referred to as "general purpose landfills" are required to meet the requirements of tougher design and operating laws.

Most of the published empirical studies tell us little or nothing about type of waste materials accepted by landfills studies, the actions taken, if any, by operators of the facilities to mitigate those factors that are likely to impact the perception of buyers and sellers of homes located close to landfills. The implication of being mute on these issues is that if the result of an empirical study shows the existence of property value impact whereas good mitigation measures are in place, 
researchers would be better-off diverting their energy to measuring something other than perception.

The methodologies applied by previous studies to capture perception will be analyzed below. Two approaches, rigorous and nonrigorous, distinguish the methodologies adopted in the studies reviewed below. The non-rigorous approach to determining the impact of a solid waste facility on property value usually entails the analysis of the sale and resale of the properties surrounding a landfills and a comparable control area, over a specified period of time (Metropolitan Service District, 1981; The Palm Beach County Solid Waste Authority, 1986). In detail the analysis involves 1 ) adjustments for differences in time of saie, number of bedrooms, garage size, basement areas, and ages between homes in the experimental group and the control group, and 2) a comparison of appreciation or depreciation rates between the experimental group and the control group. Although these studies discuss value indicators (or the theory of property value) in a limited sense, the authors fail to quantify and include the indicators in their overall analysis. Hence, these studies are classified as adopting the non-rigorous approach.

The author does not know of any rigorous empirical study conducted before the work of Havlicek et al (1971) which found that 
housing prices varied with the number of degrees a house is from prevailing downwind, and with distances from a landfill site. The Havlicek et al study has been reviewed and dismissed as methodologically inferior. As Hwang and Rudzitis (1978) pointed out Havlicek et al did not specify a clear boundary of the study area nor did it specify the range for which the regression coefficient for downwind and distance hold.

In an attempt to correct the deficiency in Havlicek's study, Hwang and Rudzitis (1978) studied the external effects of 55 landfills sites in the Chicago SMSA. They specified an impact range of three-blocks radius around the landfills and incorporated the various data derived by Havlicek et al in their study. Using the regression coefficients of absolute angle variable of $\$ 24$ per angle and the distance variable of $\$ 0.62$ per foot of distance, Hwang and Rudzitis derived the estimated external effects of a landfills site on a block basis.

There are two potential problems with the methodology of Hwang and Rudzitis. The first is the conceptual inconsistency and biases in assessed value used in their study. In terms of inconsistency, appraisal of properties usually occur at long irregular intervals of four - ten years. Hence, this introduces a measure of spatial and temporal inflexibility in any assessed property (Morrison, 1977; Saccamanno, 1979). As to 
biases, the use of Chicago's assessed value renders the results of Hwang and Rudzitis unreliable. A study by Berry and Bednarz (1975) of the variations in the ratio of property tax assessments to market values for single-family homes in Chicago found that differential assessment of land and improvements were not based on characteristics of the improvements and value of the land, but rather were based on political and other reasons. For example, results of the study suggest 1 ) that blacks were assessed at higher rates, and 2) there is favoritism on the part of the political machine: low assessment:price ratio in Mayor Daley and "machine" aldermen neighborhoods. The second problem with Hwang and Rudzitis' study is in the application of the coefficients developed by Havlicek et al (in a separate study of four landfills sites) to the 55 landfills sites. In other words, they failed to explain the reason for the generalization of the values of the two coefficients, which are derivatives of some site characteristics that are likely to vary between locations. It is therefore not surprising that Havlicek et al coefficients show decreases in property values located downwind or close to landfills while Hwang and Rudzitis calculate the total external effect per landfills site (of a three-block radius) to be only $\$ 60,000$.

In a rigorous investigation of the impact of landfills on property values, Gamble et al (1982) tested the hypothesis of a property price's 
relationship to distance to ten landfills in nine counties in southeastern, south central, southwestern, and northwestern Pennsylvania. The study also analyzed the community growth and development effects of landfills. These landfills are located "in farm country" and surrounded by "gently rolling farmland" or "on open land interspersed with a few farm woodlots". Gamble et al study compared changes in residential developments and sales prices of homes in the surrounding areas of the landfills to control area. Their intention was to test the hypothesis by measuring the economic relationship between market price of homes located within a one-mile radius of the landfills and the various characteristics of the homes and their locations, and then comparing the product to that of the control areas.

The measurement is based on the hedonic price model whereby sale prices of the homes are expressed as a function of the quality and quantity of housing (age, square feet of living space, garage spaces) and the disamenities of the location (expressed as distance of homes from the landfills). One of the conclusions of the study is that there was no evidence suggesting that the landfills had any adverse effects on growth or development in the communities in which they are located. However, the data did suggest that there was somewhat less development growth adjacent to the landfills. A separate analysis of single family dwellings 
(173) and lot properties (42) which sold in the years 1977 through 1981 in only one of the landfills (Boyertown landfill site) concluded that the "results suggests that the available data can not be used to support the proposition that proximity to the landfills in Montgomery County significantly influences property prices."

There are several problems with the study: 1) data was too small; 2) data was collected for both the study and control areas but price effects were not estimated for characteristics in the control area; 3) the method of measuring distance of homes from the landfills was not presented; 4) only a few characteristics of homes were used lage, square foot of living area and number of garage spaces); 5) the method of controlling for impact of inflation on sale prices was not presented; 6) as admitted by Gamble et al, available cross-sectional samples (18 46) are "relatively small and not conducive to much confidence in rejecting the distance to the landfills as influencing property prices;" 7) although the results show $\$ 4,200$ reduction in value per mile, the results were not significant; and 8 ) the low test statistics (test of significance), as also noted by Gamble et al can be attributed to the omission of relevant variables.

To the extent that there are deficiencies in the research design used by Gamble et al, the results may not be too surprising given the 
environmental settings in which the study took place. In underdeveloped rural areas the siting of a landfill may be a blessing in disguise because of the infrastructure such as good roads which may come with the landfills. The issue that should be raised here is that in rural areas good roads are not usually abundant as such should be controlled for in a study such as that of Gamble et al. Controlling for good roads in the rural areas may yield a different result.

In another study of a landfill in the north central portion of the San Fernando Valley in Los Angeles, Bleich et al. (1991) compared housing prices in an adjacent neighborhood to housing in two comparable areas one-half to six miles from the landfill. Using regression-based approach, Bleich et al. analyzed 1,628 sales transaction that occurred between 1978 and 1988 in three neighborhoods located within six miles of the landfills. House-specific and neighborhood variables were used in the study. Five of the eight house-specific variables, but none of the neighborhood variables were significant, thus Bleich et al. concluded that "a landfill, if well-designed and managed, can be good neighbor and have no statistically measurable negative impact on surrounding property values."

The most recent study of landfill impact was conducted by Nelson et al. (1992) on Anoka regional landfill in Ramsey, Minnesota. The 
study used sales data of 708 homes between 0.35 and 1.95 miles of the landfill, sold during 1979 to 1989 period. Unlike previous studies, the results of Nelson et al. study show that the landfill had nearly $\$ 5,000$ impact on homes for each mile away from the landfill. It should be pointed out here that whereas Nelson et al. studied a multi-purpose landfill that accepts all kinds of garbage, this particular research focused only on a limited purpose landfill that accepted only dry wastes. To reiterate, limited purpose landfills are characterized as less harmful to the environment.

From the empirical studies reviewed, there are several lessons to be learned about estimating property value impact of landfills. First, the property and neighborhood characteristics that impact property value must be selected with care and intention to specify the best model that will explain spatial and aspatial patterns of impact. Second, proximity or distance of homes from the landfill must be well defined and measured. Third, the implication of the preceding statement is that a variety of rigorous regression equations may be necessary in order to determine the best fit model(s) that is(are) adequate for estimating prices of property and neighborhood characteristics. Fourth, although some of the studies reviewed suggest the use of comparable control area, the reason for using control area, if necessary, and the method of 
selecting control area must be explained. Fifth, the effect of inflation on the dependent variable (sale price) must be controlled for or taken away.

\section{SUMMARY}

From the foregoing literature review we can conclude that the theoretical structure from which property values are determined results in at least seven classifications: quality of house, quantity of house, neighborhood land use, neighborhood socioeconomic status, neighborhood socioeconomic infrastructure, accessibility of neighborhood, and neighborhood housing market. Factors which determine where a landfill is sited, or where a specific type of landfill should be sited in a community include ownership (especially by jurisdictions that cater only to its residents), and transportation costs. Increased awareness of the environmental impact of landfills have led citizens to disregard or appreciate the savings in transportation costs associated with proximity to the facilities. Although we have seen several studies conclude that there is no property value impact of landfills on property value, resistance to sitting of landfill is all time high. Only one study of a large regional multi-purpose landfill has shown negative impact associated with sales prices. It is our hope that the 
results of this study will add or increase our knowledge in this area and how current and future landfill owners should deal with Nimbysm. 


\section{CHAPTER III}

\section{METHODOLOGY}

To reiterate, the purpose of this study is to provide insight to the arguments between landfill owners and host neighbors of landfills regarding especially the economic and social impacts of such facilities. Most of the previous studies that investigated these issues employed comparable approaches in which variables of one or several landfills and comparable neighborhoods were analyzed with least square regression (Gamble et al. 1982; Bleich et al. 1991) and without regression models (Metropolitan Service District, 1981; Palm Beach County Solid Waste Authority, 1986). Few studies focused on variables of a particular landfill and the characteristics of surrounding area using time-series data and least square regression (Nelson et al. 1992).

As mentioned earlier, the hedonic pricing approach is employed in this study to determine the true price of living close to or far from a landfill. As pointed out by Rosen (1974), at any particular location in the urban area, housing can be viewed as a package of goods consisting of structural and non-structural characteristics that home buyers take into account when they make an offer on a home. A household can buy different quantities of housing characteristics it likes by choosing 
different locations. While the price paid is a whole, the marginal hedonic prices of the structural and non-structural characteristics of the house can be estimated and then used to determine household willingness to demand/pay for a certain characteristic (Blomquist and Worley, 1981; Butler, 1982; Freeman, 1979). In this study our objective is to estimate prices of housing characteristics (including neighborhood and environmental characteristics) and does not include further estimation or determination of the demand for the characteristics.

Some researchers caution the choice of specification for the relationship between hedonic process and implicit markets because of the inherent bias in functional form of hedonic regression used to estimate demand of a housing characteristic. As Blomquist and Worley (1981) pointed out, if households can repackage characteristics by relocating, then marginal price of characteristics would not vary across sites and the functional form of the hedonic regression is simply linear. On the other hand, if households can not repackage housing characteristics across sites then the functional form is nonlinear. Nevertheless, Butler (1982) explains that since the hedonic function must be limited to housing characteristics, the question of which characteristic must be included in the determination of market price is 
not easily answered by including all characteristics in a simple linear or nonlinear hedonic regression equation. Butler also emphasize the need to check for multicolinearity problem that would likely arise.

In taking the foregoing cautions into consideration, the choice of variables for housing in the Lavele neighborhood and the landfill in particular, and the functional form will be limited to a simple linear equation that incorporates the most salient attributes of housing and neighborhood environment in the study area for which data is available.

\section{STATEMENT OF HYPOTHESIS}

Notwithstanding the problem of few studies, the review of both the empirical and theoretical researches has delineated paths to issues and variables commonly associated with property value impacts. The intention in this particular research is also to scrutinize and find answers to the following issues and hypothesis through secondary data analysis within the confines of a small research budget. The issues are:

1) the property value impact of landfills in operation located in a high density single family residential neighborhood; and

2) the property value impact of a closed landfills site located in a high density single family residential neighborhood.

These research questions imply the following hypotheses:

1) the property value impact of a landfill located in a densely populated single family residential neighborhood diminishes 
with distance away from the landfill. (That is to say, because of the odor, noise and visibility factors associated with a landfills, it is possible that property in close proximity to the landfills will experience declining value. Those properties further away from the facility may never have to encounter these traits, with the net effect that they may not experience a decline in value);

2) the property value impact of a closed landfills will be lower than the property value impact of a landfills in operation because of the lack of odor, noise, and visibility inherent in landfills operation;

3) household willingness to pay for improvement in neighborhood quality is greater than zero since host neighbors of a landfills seek compensation or closure of the facility; and

4) the regression coefficient would be the same for the three study periods (if sale prices are adjusted to the price level of the period before the landfill started operation).

The basic assumption is that buyers and sellers of homes in the study area are well informed of both the characteristics of the homes and neighborhood.

\section{GENERAL CHARACTERISTICS OF THE STUDY AREA}

To test the foregoing hypothesis, the focus of the research was narrowed to a location that is easily assessable by the author so that past operators of the landfill can be easily reached for undocumented information. The ease of finding data on sale prices and housing characteristics was another factor considered in choosing a study area. 
The old Lavele landfill in Portland, Oregon was chosen to test the validity of the hypotheses of this study. The landfill is located in the northeast section of the city, on a 23 acres of 33.5 acre site. It started operation in late 1972 and closed doors to garbage trucks in late 1982. Ownership of the landfill changed during operation but operation of the landfill was managed by one company. An interview with one of the previous owners revealed that the landfill closed because the owner raised the lease to a point unacceptable to the operator. The landfill is buffered on the north and west with a fence, on the south with Oregon Athletic Club, and on the east with trees. Neighbors were allowed to dispose their garbage at the site for free. The Oregon Department of Environmental Quality (DEQ) permitted the landfill to operate as a demolition landfill - accepting only building materials, soil, rock, concrete or asphalt.

Population in the two census tracts shared by the landfill changed a little before the landfill opened in 1970 and 1980 when the landfill closed. During this period, total population in the area decreased by three percent. The population of African-Americans in the area remained at one percent during the period, while that of whites decreased slightly from 99 percent to about 89 percent. The population 
of families with children under 18 years old decreased by nine percent during the same period.

The proportion of high school graduates in the same area in 1970 was about 70 percent, and decreased slightly to 69 percent in 1980 . The employment level for persons 16 years and older declined from 80 percent to about 70 percent between 1970 and 1980 . However, mean income level increased from approximately $\$ 11,000$ to $\$ 12,800$ during the same period.

Housing units in the same two census tracts area increased by five percent during the same period. Only one percent of the total units were vacant in 1970 while all the units were occupied in 1980 . Owner occupied units in the same two census tract area declined from 69 percent in 1970 to 66 percent in 1980, while renter occupied units increased from 31 percent to 34 percent during the period.

In 1983 the Oregon Legislature passed law requiring owners of landfills that closed after January 1, 1980 to obtain closure permit from the DEQ. This closure permit must be maintained after the site closes, even though solid waste is no longer received at the site, until DEQ determines that the disposal site no longer poses a threat to the environment. DEQ issued a closure permit for the Lavele landfill in December 1984 stipulating that the permitted activities at the site 
include bi-weekly program of monitoring the methane monitoring wells, proper service of monitoring and methane extraction system equipment, erosion control, drainage, maintenance of perimeter fence, and litter control. The landfill experienced gas (methane) migration into homes closer to the north boundary in 1983 . Thereafter an active gas collection system was installed and gas migration stopped (DEQ, 1986).

An interview with officials of the Oregon Department of Environmental Quality and one of the former operators of the landfill also revealed that there was little or no complaints by neighbors during the period the landfill was in operation. There was no action, therefore, to educate any concerned citizen (or public officials) of the extent of mitigation measures in place during operation, if any.

More than 90 percent of a two-mile radius around the landfills was zoned high density single family residential during the period the landfill was in operation. However, in 1973 and 1975 minor zone change were approved for construction of 8-unit apartments and a craft store respectively. The apartments are located 14 blocks away (west) from the landfill. There is no information on the number of owneroccupied and absentee landlords for the homes in the study area. 
In 1983-84 the comprehensive designation of the area was changed from single-family to light manufacturing and light industrial. In 1984 the owner of the landfill, Rose City Sand and Gravel Company applied to the City of Portland for a zone change that would allow it to build on the site (The Oregonian, February 1984). The application could not have been granted because the DEQ issued a closure permit later that year that stipulated monitoring of the landfills site until October 1994.

\section{CONCEPTUAL AND OPERATIONAL MODEL}

Our previous analysis has shown that: 1) residential property prices are affected by various factors; and 2) the study area is $100 \%$ developed, hence our concern here is not with the supply of new residential housing but rather with improvements and demand for the existing housing.

A general demand analysis for housing recognizes that when classes of prices are introduced into housing each monetary figure (payment) simply represents a certain quantity of utilities or values. The value distribution is dependent upon many variables (property characteristics, etc.) that influence the amount paid for a house. Some 
variables will satisfy owners' needs and others will hinder owners' satisfaction.

Following our earlier theoretical exploration, the basic equation that can explain the value distribution of single family residential property price is:

$$
P H=f(Q L, Q U, N P, N A, N S, N M, N L)
$$

where

$$
\begin{aligned}
& \mathrm{PH}=\text { the sale price of the house } \\
& \mathrm{QL}=\text { the quality of the house } \\
& \mathrm{QU}=\text { the quantity of services offered by the house } \\
& \mathrm{NP}=\text { the public service in the neighborhood } \\
& \mathrm{NA}=\text { the extent of accessibility in the neighborhood } \\
& \mathrm{NS}=\text { the socioeconomic condition of the neighborhood } \\
& \mathrm{NM}=\text { the housing market condition of the neighborhood } \\
& \mathrm{NL}=\text { the physical location of the neighborhood }
\end{aligned}
$$

The above relationship can be estimated with the multiple regression technique that yield products of a covariate analysis of linearly combined property specific variables and before-after landfills proxy variables. An F-test was carried out to determine the joint significance of all independent variables. 
The linear approach was applied by drawing references from many studies of the property value impact of various types of facilities such as public housing (Rabiega et al., 1984), and landfill (Gamble et al., 1982). A number of property specific variables were entered into a linearly specified multiple regression model so as to remove their effect and isolate those of before and after the landfills operation periods. The measurement tools of property specific variables are some of those shown in Table 2. The distance impact hypothesis was treated by including variables that represent sales before, during, and after the landfills closed. 
TABLE \|

Variables For Property Value Impact of Landfills

\begin{tabular}{|c|c|c|}
\hline $\begin{array}{l}\text { Category } \\
\text { of Attributes }\end{array}$ & $\begin{array}{l}\text { Sub-set } \\
\text { of Attributes }\end{array}$ & Variable (measurement tools) \\
\hline Property Value & & $\begin{array}{l}\text { - Individual assessed value of property } \\
\text { - Individual sale transactions of property } \\
\text { - Owner estimated value of property }\end{array}$ \\
\hline Property & $\begin{array}{l}\text { Quantity } \\
\text { Quality }\end{array}$ & $\begin{array}{l}\text { - Lot size } \\
\text { - Number of rooms } \\
\text { - Number of bedrooms } \\
\text { - Basement } \\
\text { - Garage } \\
\text { - Age } \\
\text { - Interior space } \\
\text { - Fireplace }\end{array}$ \\
\hline Neighborhood & $\begin{array}{l}\text { Accessibility } \\
\text { Public Service } \\
\text { Socioeconomic } \\
\text { Location } \\
\text { Housing Market }\end{array}$ & $\begin{array}{l}\text { - Travel time to CBD } \\
\text { - Travel time to major freeways } \\
\text { - Travel time to employment centers } \\
\text { - School expenditure } \\
\text { - Pupil-teacher ratio } \\
\text { - Improved reading score } \\
\text { - Success in college admissions } \\
\text { - Local recreation expenditure } \\
\text { - Quality of fire protection } \\
\text { - Road and street expenditure } \\
\text { - Median family income } \\
\text { - Existence of landfill at time } t \\
\text { - Proximity of property to landfill } \\
\text { - Proximity of property to road used by } \\
\text { gatiage trucks } \\
\text { - Size of landfill } \\
\text { - Land use } \\
\text { - Number of sales in impact area } \\
\text { - Number of repeat sales }\end{array}$ \\
\hline
\end{tabular}


The form of the quantitative estimation of the linear equation is as follows:

$$
\begin{aligned}
\mathrm{Pi}= & a+b 0+b 1 \times 1+b 2 \times 2+b 3 \times 3+b 4 \times 4+b 5 \times 5+b 6 \times 6 \\
& +b 7 \times 7+b 8 \times 8+b 9 \times 9+b 10 \times 10+b 11 \times 11+e
\end{aligned}
$$

\begin{tabular}{|c|c|c|}
\hline $\mathrm{Pi}$ & $=$ & a base year constant dollar sales price \\
\hline a & $=$ & an intersection to be estimated; \\
\hline b1..b11 & $=$ & $\begin{array}{l}\text { the coefficients to be estimated (or the unit } \\
\text { contributions of each variable); }\end{array}$ \\
\hline $\mathrm{X} 1$ & $=$ & age of house at time of sale; \\
\hline$\times 2$ & $=$ & lot size in square feet; \\
\hline$\times 3$ & $=$ & house size in square feet; \\
\hline$x 4$ & $=$ & number of bedrooms in the house; \\
\hline$\times 5$ & $=$ & number of bathrooms in the house; \\
\hline $\mathrm{x} 6$ & $=$ & height of house in stories; \\
\hline$x 7$ & $=$ & presence of garage (dummy variable); \\
\hline$x 8$ & $=$ & presence of fireplace (dummy variable); \\
\hline$\times 9$ & $=$ & presence of basement (dummy variable); \\
\hline$\times 10$ & $=$ & $\begin{array}{l}\text { distance of home from landfills in blocks (city blocks); } \\
\text { (represents how neighborhood is perceived) }\end{array}$ \\
\hline $\mathrm{e}$ & $=$ & $\begin{array}{l}\text { an error term (to allow for possibility that relevant } \\
\text { characteristics have been excluded and random } \\
\text { disturbances]. }\end{array}$ \\
\hline
\end{tabular}

where 
Most of the property specific variables are expected to be positively related to sale price. However, the age variable was expected to be negatively related to sale price, except in the case where older houses benefit from historic preservation programs or may have better construction and landscaping.

It is in order to state the assumptions of the above regression equation which must be maintained. These assumptions of the above regression equation are: 1) the data to be used must be representative of the variables; 2) a normal distribution of the variables; 3) the independent variables must be linearly independent of each other; and 4) all the data must be measured at interval ratios. Where any of these assumptions are violated, we will employ any of the available theoretically justified correction techniques. 


\section{VARIABLE MEASUREMENT AND DATA SOURCES}

The type of data collected for operationalizing the association of dependent and independent variables are shown below.

The Dependent Variable

The dependent variable is operationalized as follows:

SPRICE - Sales Price of individual homes before the Lavele landfills opened (1971), during the time the landfills was in operation (1979), and after the landfills closed (1986). All sales price will be adjusted to a 1972 base year.

The independent Variable

The study postulates that the following independent variables will be associated with the sale prices of homes in the Lavele landfill neighborhood.

QL - Property Quality variables:

AGE $\quad-\quad$ Age of house at sale

HSIZE - Interior Space (House Size) in square feet, at sale

GARAGE - $\quad$ Garage at sale la dummy variable; $1=a$ garage; $0=$ no garage)

FRPL $\quad-\quad$ Fire-place at sale la dummy variable; $1=$ a fireplace; $0=$ no fire-place) 
BATH - Number of bathroom, at sale

QU - Property Quantity Variables:

LSIZE - Lot Size in square feet, as sale

BDROOM - Number of Bedrooms, at sale

HEIGHT - Number of stories, at sale

BASEM - Basement la dummy variable; 1 = a basement;

$0=$ no basement)

NL - Neighborhood Location Variables:

DIST - Straight line distance (in feet) between the site of the landfills and site of the house sale.

Distance of homes from the landfill was based on the distance between center of the landfill and the nearest homes. This distance is approximately 250 feet and corresponds roughly with the width of city blocks directly on the southern portion of the study area. Homes located directly north or east or west of the landfill were grouped into 240 feet length of "blocks". That is to say, all homes within 240 feet range from the landfill were grouped into the first (or one) block, whereas homes with 241 feet 480 feet from the landfill were grouped 
into the second block. Homes located diagonally in the 45 degree angle of the northeast, northwest southeast and southwest sections of the study area were also grouped into 240 feet block ranges. The City of Portland street map microfiche file containing detailed diagram of the study area and street dimensions was used to measure the distance of homes from the landfill as described above.

\section{Data Sources for Dependent and Independent Variables}

Data for the dependent variable (sale prices) was obtained from the Oregon Multiple Listings (MLS), Volumes 1,2,3,4, for 1971, 1979 and 1986. For the independent variables, data for the key control variable - distance - was computed by the author. Data for the rest of the independent variables was obtained from the MLS volumes listed earlier and the Multnomah County, Oregon, Tax Assessor's files.

\section{SUMMARY}

The chapter has focused on the statistical method used to determine empirically the property value impact of landfills. The research questions and hypotheses were formulated, with a description of the area in which the hypotheses were tested. A complex multiple regression equation was specified for the test. The predictor variables 
and the dependent variable were also specified. The assumptions of the regression equation were stated. Finally, the method of determining distance of homes away form the landfill was clearly stated. 


\section{CHAPTER IV \\ DESCRIPTIVE ANALYSIS OF LANDFILL NEIGHBORHOOD HOUSING DATA}

The analysis of the data is presented in this chapter. To reiterate, a hypothesis was generated to investigate the property value impact of landfill. Some research questions were also generated. This chapter is divided into two sections. The first section is an explanation of the spatial distribution of homes measured by typical length of the smallest city block ( 240 feet) in the study area. The second section is an analysis of the housing market in the study area during the three periods.

\section{SPATIAL DISTRIBUTION OF HOUSING}

The distribution of homes sold by distance (in city blocks) during the three periods are shown in Table III. Data in the table show that more than 50 percent of the homes were sold during the landfill operation period are one to five blocks away from the landfill. Whereas less than 30 percent of the homes were sold before the landfill started operation and after the landfill quit operation. 
TABLE III

HOME SALE BY DISTANCE FROM LANDFILL

\begin{tabular}{|c|c|c|c|}
\hline \multirow{2}{*}{ Distance in Block * } & \multicolumn{3}{|c|}{ Year and number of homes } \\
\cline { 2 - 4 } & 1971 & 1979 & 1986 \\
\hline \hline 1 & 4 & 8 & 3 \\
\hline 2 & 3 & 11 & 4 \\
\hline 3 & 6 & 11 & 8 \\
\hline 4 & 10 & 16 & 6 \\
\hline 5 & 6 & 8 & 7 \\
\hline 6 & 9 & 8 & 9 \\
\hline 7 & 5 & 4 & 10 \\
\hline 8 & 4 & 4 & 8 \\
\hline 9 & 3 & 1 & 7 \\
\hline 10 & 4 & 5 & 9 \\
\hline 11 & 1 & - & 4 \\
\hline 12 & 1 & 2 & - \\
\hline 13 & - & 1 & 1 \\
\hline TOTAL & 56 & 79 & 76 \\
\hline
\end{tabular}

* One block in this study is equal to 240 feet.

The mean distance in 1971,1979 and 1986 are 5.5, 4.7 and 6.5 blocks respectively. Mean distance for the three periods depicts that the distance spread of homes sold when the landfill was not in operation is smaller than the distance spread of homes sold when the landfill was 
in operation. These results do not necessarily support the hypotheses that most homes sold in 1979 are closer proximity to the landfill.

\section{PERFORMANCE OF THE HOUSING MARKET}

In both relative and absolute terms, the housing market was more active in 1979 than 1971 and 1986. A summary of house sales in the Lavele landfill neighborhood is presented in Table IV.

TABLE IV

HOME SALE BY STUDY PERIOD

\begin{tabular}{|c|c|c|c|}
\hline \multirow{2}{*}{ Number of Room } & \multicolumn{3}{|c|}{ Year and number of homes } \\
\cline { 2 - 4 } & 1971 & 1979 & 1986 \\
\hline \hline 1 & $6(11 \%)$ & $2(3 \%)$ & $5(7 \%)$ \\
\hline 2 & $18(32 \%)$ & $34(43 \%)$ & $38(50 \%)$ \\
\hline 3 & $18(32 \%)$ & $38(48 \%)$ & $30(39 \%)$ \\
\hline 4 & $14(25 \%)$ & $4(5 \%)$ & $2(3 \%)$ \\
\hline 5 & - & $1(1 \%)$ & $1(1 \%)$ \\
\hline \hline TOTAL & $56(100 \%)$ & $79(100 \%)$ & $76(100 \%)$ \\
\hline
\end{tabular}

During the three periods studied, there were more homes sold in the period the landfill was in operation. The number may not necessarily depict home buyers dislike of the neighborhood. A 
comparison of addresses of home sales data show that four of the homes that sold in 1971 were resold in 1979. Another three of the homes sold in 1971 were resold in 1986 . Three of the homes sold in 1979 were resold in 1986.

The mean sale prices during the three periods are $\$ 18,090$ for $1971, \$ 48,275$ for 1979 , and $\$ 42,632$ for 1986 . These mean sale prices are consistent with those in the entire northeast area of Portland. For example, the sale price of a typical 740' home built in 1947 was $\$ 48,950$ in 1979 and $\$ 43,000$ in 1986 (Metropolitan Real Estate Report, 1981 and 1988).

The range of age of homes sold during the three study periods is shown in Table V. Most of the homes sold in 1986 are older ( 31 years and over) than those sold in 1971 and 1979. This seems to be a reflection of a built up neighborhood where only very few new houses were built during the three study period. 
TABLE V

HOME SALE BY AGE OF HOUSE

\begin{tabular}{|c|c|c|c|}
\hline \multirow{2}{*}{ Age } & \multicolumn{3}{|c|}{ Year and number of homes } \\
\cline { 2 - 4 } & 1971 & 1979 & 1976 \\
\hline $1-10$ & 2 & 6 & 2 \\
\hline $11-20$ & 15 & 9 & 2 \\
\hline $21-30$ & 19 & 30 & 4 \\
\hline $31-40$ & 4 & 15 & 40 \\
\hline $41-50$ & 6 & 3 & 6 \\
\hline over 50 & 10 & 16 & 22 \\
\hline TOTAL & 56 & 79 & 76 \\
\hline
\end{tabular}

The mean age of homes sold in 1971, 1979 and 1986 are approximately 31,33 , and 44 respectively.

House size distribution of homes sold during the study periods is shown in Table VI. Most of the homes sold in the three periods are below 1000 square feet. The smallest (520 square feet) and largest (4,250 square feet) size of homes were sold in 1971. 
TABLE VI

HOME SALE BY HOUSE SIZE

\begin{tabular}{|c|c|c|c|}
\hline \multirow{2}{*}{$\begin{array}{c}\text { House Size } \\
\text { (square feet) }\end{array}$} & \multicolumn{3}{|c|}{ Year and number of homes } \\
\cline { 2 - 4 } & 1971 & 1979 & 1986 \\
\hline \hline below 1000 & 25 & 38 & 41 \\
\hline $1001-1500$ & 20 & 33 & 30 \\
\hline $1501-2000$ & 10 & 6 & 5 \\
\hline over 2000 & 1 & 2 & - \\
\hline \hline TOTAL & 56 & 79 & 76 \\
\hline
\end{tabular}

Summary of simple statistics of data for the three periods showing the mean, standard deviation, minimum and maximum values of variables are presented in Table VII. The mean performance shown in Table VIII measures the central tendency of the observations while the standard deviation measures the dispersion of the observations for individual variable. A high standard deviation indicates that the observations for an individual variable are grouped inside a wide range around the mean. A low standard deviation indicates the observations are grouped closer to the mean (Krueckerberg and Silver, 1974). 
TABLE VII

COMPARISON OF MEAN PERFORMANCE

\begin{tabular}{|c|c|c|c|c|c|c|c|}
\hline Variable & 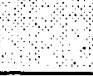 & $N$ & Mean & Std Dev. & Minimum & Maximum & Sum \\
\hline Sale Price & $\begin{array}{l}1971 \\
1979 \\
1986 \\
\end{array}$ & $\begin{array}{l}56 \\
79 \\
76 \\
\end{array}$ & $\begin{array}{l}18,090 \\
48,275 \\
42,632\end{array}$ & $\begin{array}{l}10,646 \\
12,160 \\
11,781\end{array}$ & $\begin{array}{r}6,500 \\
25,000 \\
16,250\end{array}$ & $\begin{array}{r}70,000 \\
117,000 \\
79,000\end{array}$ & $\begin{array}{l}1,013,050 \\
3,813,750 \\
3,240,060\end{array}$ \\
\hline Distance & $\begin{array}{l}1971 \\
1979 \\
1986\end{array}$ & $\begin{array}{l}56 \\
79 \\
76\end{array}$ & $\begin{array}{l}5.5179 \\
4.7089 \\
6.4605\end{array}$ & $\begin{array}{l}2.7236 \\
2.8741 \\
2.9003\end{array}$ & $\begin{array}{l}1 \\
1 \\
1\end{array}$ & $\begin{array}{l}12 \\
13 \\
13\end{array}$ & $\begin{array}{l}309 \\
372 \\
491\end{array}$ \\
\hline Lot Size & $\begin{array}{l}1971 \\
1979 \\
1986\end{array}$ & $\begin{array}{l}56 \\
79 \\
76\end{array}$ & $\begin{array}{l}5,977 \\
5,932 \\
5,863\end{array}$ & $\begin{array}{l}1,953 \\
1,658 \\
1,633\end{array}$ & $\begin{array}{l}2,000 \\
2,000 \\
3,900\end{array}$ & $\begin{array}{l}13,000 \\
10,764 \\
12,000\end{array}$ & $\begin{array}{l}334,720 \\
468,596 \\
445,567\end{array}$ \\
\hline House Size & $\begin{array}{l}1971 \\
1979 \\
1986\end{array}$ & $\begin{array}{l}56 \\
79 \\
76\end{array}$ & $\begin{array}{l}1,184 \\
1,083 \\
1,050\end{array}$ & $\begin{array}{l}557.9950 \\
330.2353 \\
270.5382\end{array}$ & $\begin{array}{l}520 \\
520 \\
600\end{array}$ & $\begin{array}{l}4,250 \\
2,538 \\
1,943\end{array}$ & $\begin{array}{l}66,300 \\
85,583 \\
79,764\end{array}$ \\
\hline Age & $\begin{array}{l}1971 \\
1979 \\
1986\end{array}$ & $\begin{array}{l}56 \\
79 \\
76\end{array}$ & $\begin{array}{l}31.2321 \\
32.8481 \\
43.7895\end{array}$ & $\begin{array}{l}15.5528 \\
16.4979 \\
18.3669\end{array}$ & $\begin{array}{l}7 \\
2 \\
2\end{array}$ & $\begin{array}{l}62 \\
68 \\
78\end{array}$ & $\begin{array}{l}1,749 \\
2,595 \\
3,328\end{array}$ \\
\hline Bedroom & $\begin{array}{l}1971 \\
1979 \\
1986 \\
\end{array}$ & $\begin{array}{l}56 \\
79 \\
76 \\
\end{array}$ & $\begin{array}{l}2.7143 \\
2.6073 \\
2.4211\end{array}$ & $\begin{array}{l}0.9670 \\
0.6872 \\
0.7351\end{array}$ & $\begin{array}{l}1 \\
1 \\
1\end{array}$ & $\begin{array}{l}4 \\
5 \\
5\end{array}$ & $\begin{array}{l}152 \\
206 \\
184 \\
\end{array}$ \\
\hline Bath & $\begin{array}{l}1971 \\
1979 \\
1986 \\
\end{array}$ & $\begin{array}{l}56 \\
79 \\
76 \\
\end{array}$ & $\begin{array}{l}1.2500 \\
1.2911 \\
1.2105\end{array}$ & $\begin{array}{l}0.6705 \\
0.4844 \\
0.4709\end{array}$ & $\begin{array}{l}1 \\
1 \\
1\end{array}$ & $\begin{array}{l}4 \\
3 \\
3\end{array}$ & $\begin{array}{c}70 \\
102 \\
92 \\
\end{array}$ \\
\hline Height & $\begin{array}{l}1971 \\
1979 \\
1986 \\
\end{array}$ & $\begin{array}{l}56 \\
79 \\
76\end{array}$ & $\begin{array}{l}1.0179 \\
1.0253 \\
1.0132\end{array}$ & $\begin{array}{l}0.1336 \\
0.1581 \\
0.1147\end{array}$ & $\begin{array}{l}1 \\
1 \\
1\end{array}$ & $\begin{array}{l}2 \\
2 \\
2\end{array}$ & $\begin{array}{l}57 \\
81 \\
77\end{array}$ \\
\hline Basement & $\begin{array}{l}1971 \\
1979 \\
1986 \\
\end{array}$ & $\begin{array}{l}56 \\
79 \\
76 \\
\end{array}$ & $\begin{array}{l}0.6071 \\
0.6709 \\
0.6053 \\
\end{array}$ & $\begin{array}{l}0.4928 \\
0.4729 \\
0.4920\end{array}$ & $\begin{array}{l}0 \\
0 \\
0\end{array}$ & $\begin{array}{l}1 \\
1 \\
1 \\
\end{array}$ & $\begin{array}{l}34 \\
53 \\
46 \\
\end{array}$ \\
\hline Fireplace & $\begin{array}{l}1971 \\
1979 \\
1986 \\
\end{array}$ & $\begin{array}{l}56 \\
79 \\
76 \\
\end{array}$ & $\begin{array}{c}* \\
0.6203 \\
0.2368 \\
\end{array}$ & $\begin{array}{c}* \\
0.4884 \\
0.4280\end{array}$ & $\begin{array}{l}* \\
0 \\
0\end{array}$ & $\begin{array}{l}* \\
1 \\
1 \\
\end{array}$ & $\begin{array}{r}* \\
49 \\
18 \\
\end{array}$ \\
\hline Garage & $\begin{array}{l}1971 \\
1979 \\
1986\end{array}$ & $\begin{array}{l}56 \\
79 \\
76\end{array}$ & $\begin{array}{l}1.0179 \\
1.3038 \\
1.3026\end{array}$ & $\begin{array}{l}0.7004 \\
0.4628 \\
0.4624\end{array}$ & $\begin{array}{l}0 \\
1 \\
1\end{array}$ & $\begin{array}{l}2 \\
2 \\
2\end{array}$ & $\begin{array}{r}57 \\
103 \\
99\end{array}$ \\
\hline
\end{tabular}

* No fireplace in homes sold in 1971. 
The Pearson Correlation Matrix showing all zero-order level of relationship among the independent variables for the three periods are presented in Tables VIII, IX, and X. 
TABLE VIII

1971 DATA

Correlation Analysis

Pearson Correlation Coefficients / Prob $>|R|$ under Ho: Rho $=0 / N=56$

\begin{tabular}{|c|c|c|c|c|c|c|c|c|c|c|}
\hline & SPRICE & DIST & LSIZE & HSIZE & AGE & BDROOM & BATH & HEIGHT & BASEM & GARAGE \\
\hline SPRICE & $\begin{array}{l}1.00000 \\
0.0\end{array}$ & & & & & & & & & \\
\hline DIST & $\begin{array}{l}0.11393 \\
0.4031\end{array}$ & $\begin{array}{l}1.00000 \\
0.0\end{array}$ & & & & & & & & \\
\hline LSIZE & $\begin{array}{l}0.53584 \\
0.0001\end{array}$ & $\begin{array}{l}-0.18265 \\
0.1779\end{array}$ & $\begin{array}{l}1.00000 \\
0.0\end{array}$ & & & . & & & & \\
\hline HSIZE & $\begin{array}{l}0.83056 \\
0.0001\end{array}$ & $\begin{array}{l}0.12499 \\
0.3587\end{array}$ & $\begin{array}{l}0.52649 \\
0.0001\end{array}$ & $\begin{array}{l}1.00000 \\
0.0\end{array}$ & & & & & & \\
\hline AGE & $\begin{array}{l}-0.45832 \\
0.0004\end{array}$ & $\begin{array}{l}0.22331 \\
0.0980\end{array}$ & $\begin{array}{l}-0.22291 \\
0.0987\end{array}$ & $\begin{array}{l}-0.27410 \\
0.0409\end{array}$ & $\begin{array}{l}1.00000 \\
0.0\end{array}$ & & & & & \\
\hline BDROOM & $\begin{array}{l}0.56057 \\
0.0001\end{array}$ & $\begin{array}{l}-0.10849 \\
0.4261\end{array}$ & $\begin{array}{l}0.34643 \\
0.0089\end{array}$ & $\begin{array}{l}0.52661 \\
0.0001\end{array}$ & $\begin{array}{l}-0.37995 \\
0.0039\end{array}$ & $\begin{array}{l}1.00000 \\
0.0\end{array}$ & & & & \\
\hline BATH & $\begin{array}{l}0.083640 \\
0.0001\end{array}$ & $\begin{array}{l}0.16129 \\
0.2350\end{array}$ & $\begin{array}{l}0.38420 \\
0.0035 \\
\end{array}$ & $\begin{array}{l}0.68236 \\
0.0001\end{array}$ & $\begin{array}{l}-0.29919 \\
0.0251\end{array}$ & $\begin{array}{l}0.43117 \\
0.0009\end{array}$ & $\begin{array}{l}1.00000 \\
0.0\end{array}$ & & & \\
\hline HEIGHT & $\begin{array}{l}0.66344 \\
0.0001\end{array}$ & $\begin{array}{l}0.22391 \\
0.0971 \\
\end{array}$ & $\begin{array}{l}0.28023 \\
0.0365\end{array}$ & $\begin{array}{l}0.74762 \\
0.0001\end{array}$ & $\begin{array}{l}-0.20324 \\
0.1330\end{array}$ & $\begin{array}{l}0.18091 \\
0.1821\end{array}$ & $\begin{array}{l}0.61287 \\
0.0001\end{array}$ & $\begin{array}{l}1.00000 \\
0.0\end{array}$ & & \\
\hline BASEM & $\begin{array}{l}0.04812 \\
0.7247 \\
\end{array}$ & $\begin{array}{l}0.03241 \\
0.8125 \\
\end{array}$ & $\begin{array}{l}0.01332 \\
0.9224 \\
\end{array}$ & $\begin{array}{l}0.02595 \\
0.8494\end{array}$ & $\begin{array}{l}0.01923 \\
0.8881\end{array}$ & $\begin{array}{l}0.14172 \\
0.2975\end{array}$ & $\begin{array}{l}0.09065 \\
0.5064\end{array}$ & $\begin{array}{l}-0.16763 \\
0.2169\end{array}$ & $\begin{array}{l}1.00000 \\
0.0\end{array}$ & \\
\hline GARAGE & $\begin{array}{l}0.13560 \\
0.3190 \\
\end{array}$ & $\begin{array}{l}0.10944 \\
0.4220 \\
\end{array}$ & $\begin{array}{l}0.19980 \\
0.1398\end{array}$ & $\begin{array}{l}0.06988 \\
0.6088 \\
\end{array}$ & $\begin{array}{l}0.16318 \\
0.2295\end{array}$ & $\begin{array}{l}0.16874 \\
0.2138\end{array}$ & $\begin{array}{l}0.11693 \\
0.3908\end{array}$ & $\begin{array}{l}-0.19772 \\
0.1441\end{array}$ & $\begin{array}{l}0.02069 \\
0.8797\end{array}$ & $\begin{array}{l}1.00000 \\
0.0\end{array}$ \\
\hline
\end{tabular}


TABLE IX

1979 DATA

Correlation Analysis

Pearson Correlation Coefficients / Prob > $|\mathrm{R}|$ under Ho: Rho $=0 / N=79$

\begin{tabular}{|c|c|c|c|c|c|c|c|c|c|c|c|}
\hline & SPRICE & DIST & LSIZE & HSIZE & AGE & BDROOM & BATH & HEIGHT & BASEM & FRPL & GARAGE \\
\hline SPRICE & $\begin{array}{l}1.00000 \\
0.0 \\
\end{array}$ & & & & & & & & & & \\
\hline DIST & $\begin{array}{l}0.22689 \\
0.0443 \\
\end{array}$ & $\begin{array}{l}1.00000 \\
0.0\end{array}$ & & & & & & & & & \\
\hline LSIZE & $\begin{array}{l}0.27263 \\
0.0151 \\
\end{array}$ & $\begin{array}{l}-0.01249 \\
0.9130\end{array}$ & $\begin{array}{l}1.00000 \\
0.0\end{array}$ & & & & & & & & \\
\hline HSIZE & $\begin{array}{l}0.70065 \\
0.0001 \\
\end{array}$ & $\begin{array}{l}0.23010 \\
0.0413 \\
\end{array}$ & $\begin{array}{l}0.11098 \\
0.3302 \\
\end{array}$ & $\begin{array}{l}1.00000 \\
0.0 \\
\end{array}$ & & & & & & & \\
\hline AGE & $\begin{array}{l}-0.45858 \\
0.0001\end{array}$ & $\begin{array}{l}0.12613 \\
0.2680\end{array}$ & $\begin{array}{l}-021332 \\
0.0591 \\
\end{array}$ & $\begin{array}{l}-0.22198 \\
0.0493 \\
\end{array}$ & $\begin{array}{l}1.00000 \\
0.0\end{array}$ & & & . & & & \\
\hline BDROOM & $\begin{array}{l}0.26305 \\
0.0192 \\
\end{array}$ & $\begin{array}{l}0.19457 \\
0.0857 \\
\end{array}$ & $\begin{array}{l}0.00463 \\
0.9677 \\
\end{array}$ & $\begin{array}{l}0.52320 \\
0.0001 \\
\end{array}$ & $\begin{array}{l}-0.23036 \\
0.0411 \\
\end{array}$ & $\begin{array}{l}1.00000 \\
0.0\end{array}$ & & & & & \\
\hline BATH & $\begin{array}{l}0.55149 \\
0.0001\end{array}$ & $\begin{array}{l}0.03404 \\
0.7659\end{array}$ & $\begin{array}{l}-0.03031 \\
0.7909\end{array}$ & $\begin{array}{l}0.63347 \\
0.0001\end{array}$ & $\begin{array}{l}-0.22058 \\
0.0508\end{array}$ & $\begin{array}{l}0.34758 \\
0.0017\end{array}$ & $\begin{array}{l}1.00000 \\
0.0\end{array}$ & & & & \\
\hline HEIGHT & $\begin{array}{l}0.52319 \\
0.0001\end{array}$ & $\begin{array}{l}0.21395 \\
0.0583\end{array}$ & $\begin{array}{l}0.06236 \\
0.5851 \\
\end{array}$ & $\begin{array}{l}0.52242 \\
0.0001 \\
\end{array}$ & $\begin{array}{l}-014106 \\
0.2150\end{array}$ & $\begin{array}{l}0.09262 \\
0.4169 \\
\end{array}$ & $\begin{array}{l}0.40475 \\
0.0002 \\
\end{array}$ & $\begin{array}{l}1.00000 \\
0.0 \\
\end{array}$ & & & \\
\hline BASEM & $\begin{array}{l}0.15396 \\
0.1755 \\
\end{array}$ & $\begin{array}{l}0.01349 \\
0.9061\end{array}$ & $\begin{array}{l}0.09875 \\
0.3866\end{array}$ & $\begin{array}{l}0.13493 \\
0.2358\end{array}$ & $\begin{array}{l}0.29752 \\
0.0077 \\
\end{array}$ & $\begin{array}{l}-0.00799 \\
0.9443\end{array}$ & $\begin{array}{l}0.03188 \\
0.7803\end{array}$ & $\begin{array}{l}-0.05861 \\
0.6079\end{array}$ & $\begin{array}{l}1.00000 \\
0.0\end{array}$ & & \\
\hline FRPL & $\begin{array}{l}0.35829 \\
0.0012\end{array}$ & $\begin{array}{l}0.14855 \\
0.1913\end{array}$ & $\begin{array}{l}-0.05081 \\
0.6565\end{array}$ & $\begin{array}{l}0.44002 \\
0.0001\end{array}$ & $\begin{array}{l}-005180 \\
0.6503\end{array}$ & $\begin{array}{l}0.31427 \\
0.0048\end{array}$ & $\begin{array}{l}0.41908 \\
0.0001 \\
\end{array}$ & $\begin{array}{l}0.12610 \\
0.2681 \\
\end{array}$ & $\begin{array}{l}0.17355 \\
0.1261 \\
\end{array}$ & $\begin{array}{l}1.00000 \\
0.0\end{array}$ & \\
\hline GARAGE & $\begin{array}{l}0.45768 \\
0.0001\end{array}$ & $\begin{array}{l}0.09626 \\
0.3987\end{array}$ & $\begin{array}{l}0.06287 \\
0.5820\end{array}$ & $\begin{array}{l}0.40104 \\
0.0002\end{array}$ & $\begin{array}{l}-0.20879 \\
0.0648\end{array}$ & $\begin{array}{l}0.25869 \\
0.0213\end{array}$ & $\begin{array}{l}0.45818 \\
0.0001\end{array}$ & $\begin{array}{l}0.24398 \\
0.0303\end{array}$ & $\begin{array}{l}0.11122 \\
0.3292\end{array}$ & $\begin{array}{l}0.46016 \\
0.0001\end{array}$ & $\begin{array}{l}1.00000 \\
0.0\end{array}$ \\
\hline
\end{tabular}


TABLE $X$

1986 DATA

Correlation Analysis

Pearson Correlation Coefficients / Prob $>|R|$ under Ho: Rho $=0 / N=76$

\begin{tabular}{|c|c|c|c|c|c|c|c|c|c|c|c|}
\hline & SPRICE & DIST & LSIZE & HSIZE & AGE & BDROOM & BATH & HEIGHT & BASEM & FRPL & GARAGE \\
\hline SPRICE & $\begin{array}{l}1.00000 \\
0.0\end{array}$ & & & & & & & & & & \\
\hline DIST & $\begin{array}{l}-0.2816 \\
0.8092\end{array}$ & $\begin{array}{l}1.00000 \\
0.0\end{array}$ & & & & & & & & & \\
\hline LSIZE & $\begin{array}{l}0.34109 \\
0.0026\end{array}$ & $\begin{array}{l}-0.07594 \\
0.5144\end{array}$ & $\begin{array}{l}1.00000 \\
0.0\end{array}$ & & & & & & & & \\
\hline HSIZE & $\begin{array}{l}0.70388 \\
0.0001\end{array}$ & $\begin{array}{l}0.04691 \\
0.6874\end{array}$ & $\begin{array}{l}0.27217 \\
0.0174 \\
\end{array}$ & $\begin{array}{l}1.00000 \\
0.0\end{array}$ & & & & & & & \\
\hline AGE & $\begin{array}{l}-0.45456 \\
0.0001\end{array}$ & $\begin{array}{l}0.33650 \\
0.0030\end{array}$ & $\begin{array}{l}-0.20673 \\
0.0732\end{array}$ & $\begin{array}{l}-026218 \\
0.0221\end{array}$ & $\begin{array}{l}1.00000 \\
0.0\end{array}$ & & & & & & \\
\hline BDROOM & $\begin{array}{l}0.47585 \\
0.0001\end{array}$ & $\begin{array}{l}0.02041 \\
0.8611\end{array}$ & $\begin{array}{l}0.06585 \\
0.5719\end{array}$ & $\begin{array}{l}0.61053 \\
0.0001\end{array}$ & $\begin{array}{l}-021357 \\
0.0640\end{array}$ & $\begin{array}{l}1.00000 \\
0.0\end{array}$ & & & & & \\
\hline BATH & $\begin{array}{l}0.59322 \\
0.0001 \\
\end{array}$ & $\begin{array}{l}0.12332 \\
0.2886 \\
\end{array}$ & $\begin{array}{l}0.12919 \\
0.2660 \\
\end{array}$ & $\begin{array}{l}0.56218 \\
0.0001 \\
\end{array}$ & $\begin{array}{l}0.26767 \\
0.0194 \\
\end{array}$ & $\begin{array}{l}0.35680 \\
0.0016 \\
\end{array}$ & $\begin{array}{l}1.00000 \\
0.0\end{array}$ & & & & \\
\hline HEIGHT & $\begin{array}{l}0.14669 \\
0.2061\end{array}$ & $\begin{array}{l}-0.01846 \\
0.8743\end{array}$ & $\begin{array}{l}-0.04716 \\
0.6858\end{array}$ & $\begin{array}{l}0.31729 \\
0.0052\end{array}$ & $\begin{array}{l}-0.05563 \\
0.6332\end{array}$ & $\begin{array}{l}0.24968 \\
0.0296\end{array}$ & $\begin{array}{l}0.19487 \\
0.0916\end{array}$ & $\begin{array}{l}1.00000 \\
0.0\end{array}$ & & & \\
\hline BASEM & $\begin{array}{l}0.27965 \\
0.0144\end{array}$ & $\begin{array}{l}0.17580 \\
0.1288\end{array}$ & $\begin{array}{l}0.15124 \\
0.1922\end{array}$ & $\begin{array}{l}0.09073 \\
0.4357\end{array}$ & $\begin{array}{l}0.14855 \\
0.2003\end{array}$ & $\begin{array}{l}0.06015 \\
0.6058\end{array}$ & $\begin{array}{l}0.01817 \\
0.8762\end{array}$ & $\begin{array}{l}-0.14298 \\
0.2179\end{array}$ & $\begin{array}{l}1.00000 \\
0.0\end{array}$ & & \\
\hline FRPL & $\begin{array}{l}0.20778 \\
0.0717\end{array}$ & $\begin{array}{l}-0.05682 \\
0.6259\end{array}$ & $\begin{array}{l}0.05974 \\
0.6082\end{array}$ & $\begin{array}{l}0.12455 \\
0.2837\end{array}$ & $\begin{array}{l}-0.03767 \\
0.7466\end{array}$ & $\begin{array}{l}0.18738 \\
0.1051\end{array}$ & $\begin{array}{l}0.08009 \\
0.4916\end{array}$ & $\begin{array}{l}-0.06433 \\
0.5809\end{array}$ & $\begin{array}{l}0.25994 \\
0.0234\end{array}$ & $\begin{array}{l}1.00000 \\
0.0\end{array}$ & \\
\hline GARAGE & $\begin{array}{l}0.65404 \\
0.0001\end{array}$ & $\begin{array}{l}0.06370 \\
0.5846\end{array}$ & $\begin{array}{l}0.29097 \\
0.0108\end{array}$ & $\begin{array}{l}0.42756 \\
0.0001\end{array}$ & $\begin{array}{l}-0.25298 \\
0.0275\end{array}$ & $\begin{array}{l}0.28694 \\
0.0120\end{array}$ & $\begin{array}{l}0.43825 \\
0.0001\end{array}$ & $\begin{array}{l}0.17528 \\
0.1299\end{array}$ & $\begin{array}{l}0.18042 \\
0.1189\end{array}$ & $\begin{array}{l}0.10460 \\
0.3685\end{array}$ & $\begin{array}{l}1.00000 \\
0.0\end{array}$ \\
\hline
\end{tabular}




\section{CHAPTER V}

\section{FINDINGS OF THE REGRESSION MODELS}

This chapter presents the type of models that were operationalized and the results of the models. An outline of the seven multiple regressions used for the empirical analysis are presented along with the reasons for using them. The first section is an explanation of the step-by-step procedure used to estimate property value impact of the Lavele landfill during the time it was in operation. The main findings of the three cross sectional multiple regression results are presented in the second section of this chapter. The casual relationship between sale price and distance in the three periods is analyzed. A discussion of the casual relationship between sale price and housing specific variables is also added. Finally, a summary of major findings of this research is discussed.

\section{THE REGRESSION MODELS}

Several regression runs were used in the analysis that follows in the next section. The regression models were used for different purposes. The regression models are as follows:

Model 1: Linear regression of 1971 data.

Model 2: Linear regression of 1979 data.

Miodel 3: Linear regression of 1986 data. 
Model 4: Linear regression of combined unadjusted 1971, 1979 and 1986 data.

Model 5: Linear regression of 1979 data (sale price adjusted to 1971 price level).

Model 6: Linear regression of 1986 data (sale price adjusted to 1971 price level).

Model 7: $\quad$ Linear regression of combined 1971, 1979 and 1986 data (sale price for 1979 and 1986 adjusted to 1971 price level).

The purpose of models 1,2 and 3 was to estimate the quantitative impacts of each independent variable on price of single family homes in the Lavele landfill neighborhood. Of utmost importance is to estimate the price effect of the distance variable on sale price of homes before the landfill opened, during the landfill operation, and after the landfill closed.

Models 4, 5, 6, and 7 were employed for the purpose of determining if there is a difference in structural and non-structural changes in the Lavele landfill neighborhood that occurred in the three time periods. Determining such differences is important especially to confirm if there is a difference in how the neighborhood was perceived before the landfill began operation and after it closed. Using data from these four models a Chow Test was operationalized to test the hypothesis that there were differences between the regression coefficients of the models. 


\section{INTERPRETATION OF REGRESSION RESULTS}

In order to understand how distance from the old quarry site (which later became the Lavele landfill) affected prices of homes before the landfill started operation, multiple regression procedures were used. Distance of homes sold in 1971 from the landfill was used to represent how the neighborhood was perceived before the landfill started operation. The independent variables which includes distance and house characteristics (lot size, house size, age, number of bedrooms, number of bath, height, basement, fireplace and garage) were regressed against sale prices of the homes. However, fireplace was absent from all the homes in the study area that were sold in 1971. Hence, fireplace is absent from Model 1 (the 1971 regression equation).

As shown in Table XI, the regression estimating price effect of distance for all homes sold in 1971 had an adjusted coefficient of determination (R2) which is 0.8540 with an F-ratio of 36.75 . The results show that all the independent variables jointly explained 85.4 percent of all the variations in sale prices of homes sold before the landfill started operation.

We have to remember that the methodology of this research implies estimating the quantitative impact of each independent variable on sale prices. However, our main purpose is to estimate the quantitative impact of distance which will help us understand how home buyers and sellers 
perceived the characteristics of the Lavele neighborhood. The regression results show that mean property value rose with respect to distance from the landfill. The increase is estimated at $\$ 200$ per block away from the landfill. 
TABLE XI

REGRESSION RESULTS FOR THE THREE PERIODS

Parameter Estimates and Analysis of Variance

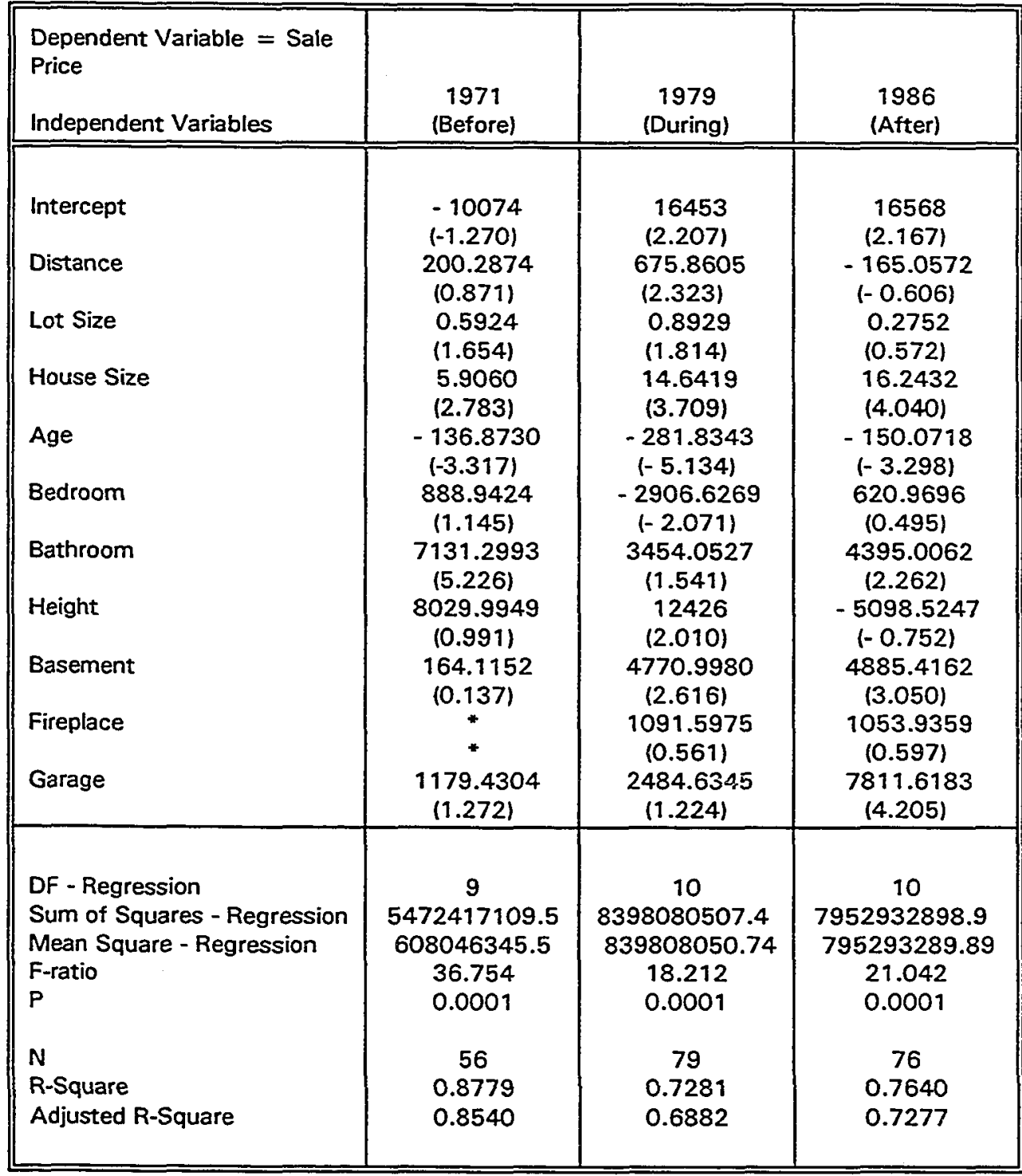

* t-value in parenthesis

* No fireplace in homes sold in 1971 
However, distance coefficient turned out to be negatively associated with sale prices. That is to say, there is no evidence that property value rose with distance. The distance coefficient was not significant at 0.05 percent level of two-tailed test. In this instance, the hypothesis that the property value impact of a landfill diminishes with distance from the landfill is not supported by statistical results of this study.

All the independent variables in the 1971 model had the expected signs. Among the independent variables. house size, age and bathroom relate positively with sale price, whereas height and basement turned out to be negatively associated with sale prices. Bathroom was statistically significant at the 0.05 level, and house size and age were significantly at the 0.10 level.

The correlation analysis show that lot size, bedroom, and height are correlated with sale price at 0.05 significant level. Basement and garage are not correlated with sale prices nor with any other variable. The correlation analysis show also that lot size, bedroom and height were highly correlated with house size and therefore added no new information to the equation.

The same independent variables including fireplace were regressed against sale prices of homes sold in 1979. The regression results show that the adjusted coefficient of determination (R2) is 0.6882 with an F-ratio of 18.21. This result show that all the independent variables jointly 
explained 68.82 percent of all the variations in sale prices of homes sold in the period the landfill was in operation.

The results of the regression further show that the mean property value rose with respect to distance from the landfill. The increase which was estimated at $\$ 676$ represents the amount at which home values rises for each block the home is located away from the landfill. Using the mean sale price data for $1979(\$ 48,275)$ and the parameter estimate for distance the percentage increase in mean home value was estimated to be one percent per block away from the landfill.

Unlike the 1971 results, the distance coefficients was positively associated with sale price. That is to say, there is a very strong evidence that property value rose with distance away from the landfill. The distance coefficient was significant at the 0.05 percent level of two-tailed test. Among the independent variables in the 1979 model, only bedroom does not have the expected sign. Lot size, house size, age, height and basement relate positively with sale price. The correlation analysis show that house size, age, bathroom, height and garage are correlated with sale price at 0.05 significance, whereas lot size, bedroom and fireplace are correlated with sale price at 0.10 significance level of two tail test. The correlation analysis show also that bedroom, height, bathroom, and fireplace are correlated house size and therefore added no new information to the equation. 
The same independent variables including fireplace were regressed against sale prices of homes sold in 1986. The regression results show that the adjusted coefficient of determination (R2) is 0.7277 with an F-ratio of 21.04. The result show that all the independent variables jointly explained 72.77 percent of all the variations in sale prices of homes sold after the landfill closed.

The estimated coefficient for the distance variable on sale prices is very different from those of 1971 and 1979. The parameter estimate was negative. That is to say, the mean property value did not rise with respect to distance; instead the mean property value declined by $\$ 165$ per block away from the landfill. However, this result of the distance coefficient turned out to be negatively associated with sale prices. Although there is no association between distance and sale prices, one can infer that the proposed conversion of the landfill into an amenity (golf range) before the landfill closed could have strengthened the housing market for homes in the landfill neighborhood.

Among the other independent variables in the 1986 model, height does not have the expected sign. House size, age, bathroom, basement and garage relate positively with sale prices, whereas lot size, bedroom, and fireplace turned out to be negatively associated with sale prices. The positive relationship between sale price and house size, and garage is significant at the 0.05 level, whereas the positive relationship between sale 
price and age, bathroom, and basement is significant at the 0.10 level. The correlation analysis show that bedroom, bathroom and garage were correlated house size and therefore added no new information to the equation.

\section{POOLED MODEL RESULTS}

As stated earlier in this chapter, the price adjusted Models number 4 , 5,6 , and 7 were employed for the general purpose of establishing whether the separate models were necessary to capture or quantify perception on property prices before, during and after operation of the landfill. The following Chow Test (Chow, 1960) formula was used for the assessment:

$$
F=\frac{\text { RRSS }- \text { URSS } /(k+1)}{\text { URSS//n1 } 1+n 2+n 3-k+3)}
$$

where:

RRSS $=\quad \begin{aligned} & \text { restricted residual sum of squares derived from } \\ & \text { the regression of the pooled data of the three } \\ & \text { periods. }\end{aligned}$
URSS $\quad \begin{aligned} & \text { unrestricted residual sum of squares derived from } \\ & \text { the separate three regressions of the three } \\ & \text { periods. }\end{aligned}$
$\mathrm{n1} \quad \begin{aligned} & \text { number of cases for the period before the landfill } \\ & \text { opened. }\end{aligned}$
$=\quad \begin{aligned} & \text { number of cases for the period the landfill was in } \\ & \text { operation. }\end{aligned}$




$$
\begin{aligned}
& \text { n3 }=\text { number of cases for the period the landfill closed. } \\
& \text { k }=\text { number of parameters or regressors. } \\
& \text { Reading: } F=\frac{(63769407161.1-2551950001.5) / 11}{6353313456 / 179} \\
& F \quad=9.79>F_{C}=1.87 \\
& \mathrm{~F} \quad>\quad \mathrm{FC}
\end{aligned}
$$

The result, $F$ ratio of 9.79 is greater than the critical $f$ ratio of 1.87 at the 5 percent significance level. For this particular test, this implies that there are significant differences in the coefficients. Therefore, the hypothesis that there are no differences in the coefficient is rejected. The conclusions that can be draw from this assessment are: a) that the impact of the operation of the landfill dissipated when all models/data are combined and regressed to 1971 price level; and b) that values of all homes would have rose in the long-run (as anticipated by the owners) in the absence of the operation of the landfill. It is therefore statistically appropriate to separate the period of operation and no operation in order to capture the perceived impact of the landfill on property value. 


\section{SUMMARY}

The research hypothesis were supported in the three main models employed in this study. By exploring the casual relationship between property value and landfill it was determined that Lavele landfill was perceived by home buyers and sellers as an environmental risk, and their general attitude was reflected in the sales prices of homes in the period the landfill was in operation. Proximity to the landfill when it was in operation was found to be important determinant of sale price. Statistically significant association was found between distance away from the landfill and sale prices. On the other hand, the relationships between sale prices and distance away from the landfill before it opened and after it closed were found to be statistically insignificant. Despite the findings of other studies as outlined earlier in Chapter 11 , the result of this study goes to support the allegations of citizens group such as CRAP and GAG, that operation of all kinds of landfill will affect property value. 


\section{CHAPTER VI \\ CONCLUSIONS AND RECOMMENDATION}

It is important to note that landfills are classified as noxious facilities. Despite the need and importance of such facilities in our society, their existence in or near residential areas or neighborhoods has not been welcomed since citizens became aware of negative externalities associated with their operations. Improvements in the technology of landfilling have been remarkable, especially at new big regional landfills and show that most of the negative environmental impacts associated with landfills can be controlled (U.S EPA 1991). The technological improvements are not readily capitalized into the property value of homes in the vicinity of such landfills. Educating citizens and public officials, including Tax Assessors about technological improvements associated with a landfill operation is very important otherwise their perception and belief about operation of a landfill will not be accurately reflected in residential property value. The results of this study will be very helpful in guiding how we discount landfill proximity to residential property.

\section{THE SIGNIFICANCE OF THIS STUDY}

The literature suggests that the location of landfills are partly determined by existing land use regulation and environmental requirements 
that aim at minimizing operational and technical risks. The level of success in minimizing technical risk is location dependent. Landfilling on porous soil increases the chances of ground water contamination whereas landfilling on soil that is rich in clay minimizes ground water pollution. However, the level of perceived risk is not necessarily tied to any geographical area or certain locations.

The literature suggests that the perceived risk associated with landfill operation are common: air pollution from garbage trucks, noise, litter, surface water and ground water pollution. The literature also suggests there are certain mitigation measures which landfill operators can use to minimize or reduce perceived risk. Increasing citizens and public officials' awareness of the existence of mitigation measures used by landfill operators will most likely minimize perceived risks associated with landfills, especially at limited purpose landfills.

The perceived risks associated with the landfill investigated in this study could equally be minimized if citizens and public officials alike are aware of the mitigation measures used by the operators. The findings of this study, therefore, may be generalized for the perception of the impact of landfill proximity to residential property.

As the literature suggests, the use of various compensation strategies by facility owners or sponsors to diffuse neighborhood opposition to landfill operation and siting tend to equate the strategies to 
equity redistribution of landfill burden. This study pointed out the problem with this approach and showed why it is necessary to measure first the magnitude of landfill burden and then use the later as a tool for determining how to redistribute landfill burden equitably.

The focus of the methodology of this research which is on the Lavele landfill neighborhood and not extended to a comparable area represents an important departure from most of the previous studies. This study and that of Nelson et al. (1992) focused mainly on the study area and coincidentally the results of both show landfills do impact property value. Although the methodology and type of landfill investigated in this study and that of Nelson et al. are different, it is important for future studies of landfill impact to consider seriously not to use comparable approach or methodology.

Although the most important independent variable in this study was distance between the landfill and homes, the relationship between the other independent variables and sales prices, and among themselves are consistent with the findings of Bleich et al. (1991). For example, the results of the three models show that bedroom and bathroom and lot size are correlated with house size. These results suggests that the bigger the size of the house, the more likely it will have more bedrooms, bathroom, stories and a fireplace. 
From a theoretical point of view, the findings of this research have contributed to the study of variables accounting for variations in property value. Landfills should be seen as a neighborhood attribute that could have economic as well as social implications. Theoretically sellers and buyers of residential property attempt to capitalize neighborhood attributes into property value (Li and Brown, 1980; Jud and Watts, 1981; Aaron, 1885). The housing prices that emerge from the capitalization represents the results of combined perception of the externalities that could alter the equilibrium set of prices in a neighborhood housing market. The results of this research will help to minimize the alteration in the behavior of sellers and buyers in a "landfill neighborhood housing market".

The findings of this research have implications for the theory of value-based planning that influence existing land use regulation. The theory assets that land should be used to yield its maximum economic benefit to the owner. This theory assumes and implys that land used for landfills will not yield its maximum economic benefit to the owner. Results of this research has shown that the operational effect of a landfill as perceived by sellers and buyers of residential property are just short term and do not include long term effects such as (potential) underground contamination in the area. The findings also suggest that if landfills are properly regulated (with sound operating and post-closure requirements) and converted into other uses (such as recreation facilities) prices of homes 
in the vicinity will likely increase after closure. If properly zoned or regulated land used for landfill would yield maximum economic benefit to the owner.

\section{POLICY IMPLICATIONS}

As shown in this research, local governments confronted by NIMBY or GAG or CRAP have debated whether there could indeed be any perceived risk when technical risk associated with landfills is considerably reduced. Public and private landfill operators, as well as state legislatures and host neighbors of landfills have grappled with type of compensation to propose or provide in order to offset any impact of landfills. A leading scholar of compensation theory, O'Hare (1977) and others such as Kunreuther and Kleindorfer (1986), Sullivan (1990) and Swallow et al. (1992) advocate auctioning the facility to the community demanding the least compensation.

Some public agencies and private parties who are eager to site new landfills or expand existing landfills and pay compensation are asking questions such as: how much compensation is fair for host neighbors of landfill? how much should the disposal fees be increased in order to raise enough money to support a neighborhood enhancement fund? how is such fund to be spent? 
From a policy standpoint, state and local governments believe that offering so called "host fees" collected and distributed to host neighbors of landfills or to communities willing to accept a new landfill will ease the shortage of landfills or landfill capacity. A policy question that arises from the Metro or Chamber and Charles City/County compensation arrangements is whether the royalty is enough, not enough or too high. If auctioning or negotiating for a royalty is acceptable as a means of eliminating property value impact and easing shortage of landfill capacity, then state and local governments should adopt the following policies:

1) all risks associated with landfill engineering and operation, including spatial and aspatial distribution of the risks must be studied and made available to the public;

2) all possible methods of eliminating the risks, including engineering, economic and social approaches should be studied and made available to the public;

3) disposal fees must include the estimated costs for mitigating all known risks associated with landfill engineering and operation; and

4) host fees or neighborhood enhancement funds should not be larger or smaller than estimated cost of mitigating the economic and social risks.

The results of this study will guide compensation researchers in estimating the true cost of mitigating economic and social risks associated with landfill operation. The results of this research will also guide policy makers in understanding how economic and social disamenities associated 
with landfill operation could be factored into host fees or surcharge on disposal fees so that an equity distribution of landfill burden can be achieved. It must be noted that if the compensation or host fee offered by an operator or demanded by home owners is too high the entire users of the landfill will likely bear the burden of high disposal fees needed to finance the compensation unless the compensation is financed by a special fee or surcharge on waste from outside the host jurisdiction of the landfill.

Other policy areas in which the results of this research will be very useful are land use regulation and the valuation of homes by Tax Assessors and appraisers. Results of this study can be used jointly with those of other studies of property impact to determine the appropriateness of various land use regulations in the vicinity of demolition or limited purpose landfills. Results of this research will be useful to Tax Assessors and real estate appraisers in estimating the impact of a limited purpose landfill on property value.

\section{SUGGESTIONS FOR FUTURE RESEARCH}

Based on the conclusions of this research, compensation theorists have not established a clear link between amount of compensation demanded and the potential impact of landfills on property value. There is need for further research to establish compensation formula/s that could be applied to host neighborhoods of landfills. 
This research has also concluded that the conversion of a limited purpose landfill site into an amenity such as golf range may have been instrumental in restoring the stability in the neighborhood housing market. There is still need for further research on the type or range of amenities that could stabilize the housing market after closure of a landfill, especially for multi-purpose landfills. 


\section{REFERENCES}

Aaron, H.J. (1985). "Rationale For a Housing Policy" in Mitchel, J.P. (ed), Federal Housing Policies and Programs, (Center for Urban Policy Research, Rutgers University, New Brunswick, N.J.); pp 19-38

Alonso, W. (1964). Location and Land Use, (Cambridge, Massachusetts, Harvard University Press).

Berry, B. and Bednarz, R.S. (1975). "A Hedonic Model of Prices and Assessments for Single Family Homes: Does the Assessor Follow the Market or the Market Follow the Assessor?" Land Economics, Vol. 51, pp 21-40.

Berry, B.J.L. (1962). The Commercial Structure of American Cities: a review (Chicago).

Berry, B.J.L. (1967). The Geography of Market Centers and retail Distribution (Englewood Cliffs, N.J.: Prentice-Hall, Inc.).

Bleich, D.L., Findlay, N.C. and Phillips, G.M. (1991). "An Evaluation of the Impact of a Well-Designed Landfill on Surrounding Property Values", Waste Age, August 1991, pp. 55-58.

Bloomquist, G. and Worley (1981). "Hedonic Prices, Demands for Urban Housing Amenities, and Benefit Estimates," Journal of Urban Economics, Vol. 9, pp 212-221.

Brookshire, D.S., Thayer, M.A., Schulze, W.D., and D'Arge, R.C. (1982). "Valuing Public Goods: A Comparison of Survey and Hedonic Approaches." American Economic Review, Vol. 72, pp 165-177.

Brueckner, J.K. and Colwell, P.F. (1983), "A Spatial Model of Housing Attributes: Theory and Evidence," Land Economics, Vol. 59, pp 59-69. 
Burkardt, (1971). "Impact of Highways on Urban Neighborhoods: A Model of Social Change." (Highway Research Record, No. 356, Washington D.C.)

Burnett, A. and Moon, G. (1983). "Community Opposition to Hostels for Single Homeless Men," Area, Vol.15, No.2, pp 161-167.

Butler, R.V. (1982). "The Specification of Hedonic Indexes for Urban Housing," Land Economics, Vol. 58, pp 96-108.

Chow, G.C. (1960). "Test of Equality Between Sets of Coefficients in Two linear Regressions," Econometrics, Vol. 28, \#3, pp 591-605.

Coleman, R.P. (1978). "Attitudes Towards Neighborhoods: How Americans Choose to Live." Working Paper \#49 (Harvard-MIT Joint Center for Urban Studies, Cambridge, Mass.)

Cox, K. R. and Johnston, R. J. (eds) (1982). Conflict, Politics, and the Urban Scene (New York, St. Martins Press).

Dear, M. (1977). "Locational Factors in the Demand for Mental Health Care," Economic Geography, Vol. 53, pp 223-240.

Dear, M. (1977). "Impact of Mental Health Facilities on Property Values," Community Mental Health Journal, Vol. 13, pp 150-157.

Dear, M. (1978). "Planning for Mental Health Care: A Reconsideration of Public Facility Theory," International Regional Science Review, Vol. 3, pp 93-111.

Dear, M. (1992). "Understanding and Overcoming the NIMBY Syndrome,". Journal of the American Planning Association, Vol. 58, No.3, pp. 288-300. 
Dolan, L.W. and Wolpert, J. (1982). "Long Term Neighborhood Property Impacts of Group Homes for Mentally Retarded People," Discussion Paper Series, (Princeton, N.J.; Woodrow Wilson School Discussion Paper Series, Princeton University)

Downs, A. (1981). Neighborhood and Urban Development, (The Brookings Institution, Washington, D.C.)

Environmental Protection Agency (1991). "Solid Waste Disposal Facility Criteria: Final Rule - 40 CFR Parts 257 and 258," Federal Register, Rules and Regulations, Vol. 56, No. 196.

Epple, D. (1987). "Hedonic Prices and Implicit Markets: Estimating Dernand and Supply Functions for Differentiated Products," Journal of Political Economy, Vol. 95, pp 59-80.

Farber, S. (1986). "Market Segmentation and the Effects on Group Homes for the Handicapped on Residential Property Values," Urban Studies, Vol. 23, pp 519-525.

Forester, J. (1987). "Planning In the Face of Conflict: Negotiation and Mediation Strategies in Local land Use Regulation, " Journal of the American Planning Association, Summer, pp 303-314.

Freeman, A.M. (1979). "The Hedonic Price Approach to Measuring Demand for Neighborhood Characteristics," in Segal, D. (ed.), The Economics of Neighborhood (New York, Academic Press Inc.).

Freeman, A.M. (1979). "Hedonic Prices, Property Values and Measuring Environmental Benefits: A Survey of the Issues," Scandinavian Journal of Economics, Vol. 81, pp 154-173.

Freeman, A.M. (1979). The Benefits of Environmental Improvements: Theory and Practice, (Baltimore, John Hopkins University Press) 
Gamble, H.B. and Dowing, R.H. (1984). "Effects of Sanitary Landfills on Property Values and Residential Development," in Majundar, S.K. and Miller, E.W. (eds.) Solid and Liquid Wastes: Management, Methods and Socioeconomic Considerations, (Pennsylvania, The Pennsylvania Academy of Science)

GRCDA Newsletter. (1988). "Nimby, A Public Health Problem," (GRCDAthe Association Of Solid Waste Management Professionals, Silver Spring, MD)

Gittel, M. (1980). Limita to Citizen Participation, (Beverly Hills, Calif.: Sage Publications)

Gladwin, T.N. (1980). "Patterns of Environmental Conflict Over Industrial Facilities in the United States, 1970-1978," Natural Resources Journai, Vol. 20, pp 243-274.

Golledge, R.S., Clark, W.A.V., and Rushton, G. (1966). "The Implications of the Consumer Behavior of a Dispersed Farm Population in lowa," Economic Geographv, Vol. 42, pp 265-272.

Goodall, B. (1974). The Economic of Urban Areas, (New York, Pergamon Press).

Gosh, A. and McLafferty, S. (1982). "Locating Stores in Uncertain Environments: A Scenario Planning Approach," Journal of Retailing, Vol. 58 (Winter), pp 5-22.

Gosh, A. and McLafferty, S. (1984). "A Model of Consumer Propensity for Multipurpose Shopping," Geographical Analysis, Vol. 16 (July), pp 244249.

Goulet, P. G. (1979). Real Estate: A Value Approach, (Encino, California, Glencoe Publishing Co.). 
Griliches, Z. (1971). Price Indexes and Quality Change, (Cambridge, Mass: Harvard University Press).

Halvorsen, R. and Pollakowski, H.O. (1981). "Choice of Functional Forms For Hedonic Price Equations," Journal of Urban Economics, Vol. 10, No. 1, pp37-49.

Harrison, D. and Rubenfeld, D.L. (1978). "Hedonic Prices and the Demand for Clean Air," Journal of Environmental Economics and Management, Vol. 5 (March), pp 81-102.

Havlicek, J., Richardson, R., and Davies, L. (1971). "Measuring the Impact of Solid Waste Disposal Site Location on Property Values," Urban

Economics Report. No.65, University of Chicago, Chicago.

Heilbrum, J. (1981). Urban Economics and Public Policy (New York, St. Martins Press, Inc.).

Heiman, M. (1990). "From 'Not in My Backyard!' to 'Not on Anybody's Backyard!': Grassroots Challenge to Harzardous waste facility Siting." Journal of the American Planning Association, Summer, pp 359-362.

Hwang, E. and Rudzitis, G. (1978). "The External Costs of Sanitary Landfills," Journal of Environmental Svstems, Vol. 7 (4), pp 301-308.

Huang, E. (1982). "Impact of Environmental Design on Residential Crowding," Unpublished Ph.D. Dissertation, Portland State University, Portland, Oregon.

Huff, D.L. (1981). "Retail Location Theory," in R. Stampf and E. Hirschman (eds.), Theory in Retialing: Traditional and Non Traditional Sources, (Chicago: American Marketing Association). 
IAAO, (1969). Assessing and The Appraisal Process, (Chicago, Illinois, International Association of Assessing Officers).

Johnson, C. and Pattit, C.L. (1986). "The Impact on Property Values of Solid Waste Facilities," Technical Bulletin 86-1, National Solid Waste Management Association, Washington, D.C.

Jud, G.D. and Watts, J.M. (1981). "Schools and Housing Values," Land Economics, Vol. 57, No.3, pp 459-470.

Jud, G.D. (1980). "The Effects of Zoning on Single Family Residential Property Value: A Case Study of Charlotte, North Carolina." Land Economics, Vol. 56 (May), pp 142-54.

Kain, J.F. and Quigley, J.M. (1975), "Measuring the Volume of Housing Quality," Journal of the American Statistical Association, Vol. 65 (June), pp 532-46

Koehler, S.N. (1987). "The Plant Won't Hurt Property Value," Waste Age, Sept., pp 117-122.

Krueckeberg, D.A. and Silvers, A.L. (1974). Urban Planning Analysis: Methods and Models, New York, John Wiley and Sons.

Kunrenther, H. and Kleindorfer, P.R. (1986). "A Sealed-Bid Action Mechanism for Siting Noxious Facilities," American Economic Association: Papers and Proceedings, Vol. 70, No.2, pp 295-299.

Lea, A.C. (1979). "Welfare Theory, Public Goods and Public Facility Location," Geographical Analysis, Vol. 11, No.3, pp 217-239.

Leonardi, G. (1978). "Optimum Facility Location by Accessibility Maximizing," Environment and Planning, A, Vol. 10, pp 1287-1305. 
Li, M.M. and Brown, H.J. (1980). "Micro-Neighborhood Externalities and Hedonic Housing Prices," Land Economics, Vol. 56, pp 125-141.

Mandelker, D. (1974). "The Role of Zoning in Housing and Metropolitan Development," in Listokin, D. (ed.), Land Use Controls: Present Problems and Future Reform, (New Brunswick, N.J., Rutgers University, Center for Urban Policy Research).

Maser, S.M., Riker, W.H. and Rosett, R.N. (1977). "The Effects of Zoning and Externalities on the Price of Land: An Empirical Analysis of Monroe County, New York," The Journal of Law and Economics, Vol. 20, pp 111132.

McAllister, D.M. (1976). "Efficiency and Equity in Public Facility Location," Geographical Analysis, Vol. 8, pp 47-63.

McDonald, J.F. (1980). "The Use of Proxy Variables in Housing Price Analysis," Journal of Urban Economics, Vol. 7, pp 75-83.

Melosi, Martin (1981). Garbage in the Cities: Refuse, Reform, and the Environment 1880-1980, College Station, Texas A\&M Press.

Metropolitan Service District (1981). Wildwood Sanitary Landfill Feasibility Study, (Portland, Oregon; Prepared by $\mathrm{CH} 2 \mathrm{M}$ Hill Northwest, Inc.), Vol. 1.

Metropolitan Service District (1987). Valuation of the Potential External Effects At Selected Types of Prototypical Solid Waste Facilities, prepared by ECO Northwest.

Metropolitan Service District (1991). Illegal Dumping Plan (Metro, Portland, Oregon), Chapter 4 to the Regional Solid Waste Managament Plan

Metropolitan Council of Twin Cities Area (1982), Compensation and Mitigation: Dealing with the Adverse Impact of Solid Waste Disposal Facilties, (Metro, St. Paul, Minnesota). 
Michaels, M. (1990). "Speaking The Language: Siting By Communication." World Wastes, September, pp 45-48.

Miller, N.G. (1982). "Residential Property Hedonic Pricing Models: A Review," in Sirmans, C.F. (ed), Research in Real Estate, Vol. 2, (JAl Press, Inc., Greenwich, Conn.)

Mills, E. S. (1978). The Economics of Environmental Quality, (W.W. Norton and Company, N.Y.)

Mishan, E.J. (1974). "The Economics of Disamenity," Natural Resources Journal, Vol. 14, pp 55-86.

Morrison, P.S. (1977). "Data Sources on Residential Cahange and the Housing Market," Major Report No. 10, Center for Urban and Community Studies, University of Toronto, March.

Muth, R.F. (1969). Cities and Housing, (Chicago, University of Chicago Press).

Muth, R.F. (1975). Urban Economic Problems (New York, Harper and Row)

National Research Council. (1973). Environmental Quality and Social Behavior - Strategies for Research, (National Academy of Sciences, Washington, D.C.)

National Solid Waste Management Association. (1988). Landfill capacity in the US: How Much Do We Really have? Washington, D.C.

Nelson, A.C., Genereux, J. and Genereux, M. (1992). "Price Effects of Landfills on House Values," Land Economics, Vol. 68, No.4, pp 359-365. 
Nourse, H.O. (1963). "The Effects of Public Housing on Property Values in St Loius," Land Economics, Vol. 39, pp 433-41.

Oates, W.E. (1969). "The Effects of Property Taxes and Local Public Spending on Property Values: An Empirical Study of Tax Capitalization and the Tiebout Hypothesis," Journal of Political Economy, Vol. 77, pp 957971.

O'Hare, M. (1977). "Not On My Block You Don't: Facility Siting and the Strategic Importance of Compensation," Public Policy, Vol. 25, pp 407458.

Ohls, J.C., Weisberg, R.C. and White, M.J. (1974). "The Effects of Zoning on Land Values," Journal of Urban Economics, Vol. 1, pp 428-444.

Ohsfeldt, R.L. and Smith, B.A. (1985). "Estimating the Demand for Heterogenous Goods," Review of Economics and Statistics, Vol. 67, pp 165-171.

Ohsfeldt, R.L. and Smith, B.A. (1988). "Assessing the Accuracy of Structural Parameter Estimation in Analysis of Implicit Markets," Land Economics, Vol. 64, pp 135-146.

Olsen, E.O. (1969). "A Competitive Theory of the Housing market," American Economic Review, Vol. 59 (September), pp 612-622.

Oregon Departrirent of Revenue, Assessment and Appraisal Division. (1977). The market Data Approach to Value: A Self-Instructional Course for Assessors and Appraisers, (Salem, Oregon, Oregon Department of Revenue)

Oregon Department of Environmental Quality. (1993). Oregon Stete Integrated Resource and Solid Waste Management Plan - 1995-2005, (Portland, Oregon, DEQ), August. 
Parson, G. (1986). "An Almost Ideal Demand System for Housing Attributes," Southern Economic Journal, Vol. 53, pp 347-363.

Pigou, A.C. (1920). The Econimics of Welfare (New York, Macmillan)

Poon, L.C.L. (1978). "Railway Externalities and Residential Property Prices," Land Economic, Vol. 54, pp 218-227.

Popper, F.J. (1981). "Siting LULUs," Planning, Vol. 47, pp 12-15.

Rabiega, W.A., Lin, Ta-Win, and Robinson, L.M. (1984). "The Property Value Impacts of Public Housing Projects in Low Income and Moderate Density Residential Neighborhoods," Land Economics, Vol. 54, pp 218227.

Ratcliff, R.U. (1967). "Current Practices in Income Property Appraisal - A Critique," The Center for Real Estate and Urban Economics, Institute of Urban and Regional Development, University of California, Berkeley.

Reilly, W.J. (1931). The Law of Retail Gravitation, (New York, Knickerbocker Press)

Rose, J.B. (1993). "A Critical Assessment of New York City's Fair Share Criteria," Journal of the American Planning Association, Vol. 59, \#1, pp 97-100.

Rosen, S. (1974). "Hedonic Prices and Implicit Markets: Product Differentiation in Pure Competition," Journal of Political Economy. Vol. 82, pp 34-55.

Rutledge, John K. (1986). "Three Approaches to Real Estate Appraisal," The Real Estate Appraiser and Analyst, Spring, pp 12-14. 
Saccomano, F.F.(1979). "A Hedonic Price Index For Housing in Metropolitan Toronto 1961-1971," Research Paper \#103, The Center for Urban and Community Studies and The Department of Civil Engineering, University of Toronto.

Schafer, R.(1972). "The Efffects of BMIR Housing on Property Values," Land Economics, Vol. 48 (August), pp 262-86.

Schmutz, G. L. (1944). The Appraisal Process (Published by Author and Distributed by Minetta Miller, 633 South La Brea Ave., Los Angeles, CA).

Seley, J.E. (1983). The Politics of Public Facility Planning (Lexington, Mass.: Lexington Books).

Siebert, H. (1981). Economic of the Environment (Lexington, Mass., D.C. Heat and Company).

Smith, V.K., and Desvousges, W.H. (1986). "The Value of Avoiding A LULU: Hazardous Waste Disposal Sites," Review of Economic and Statistics, Vol. 68, pp 293-299.

Sternlieb, G. and Sagalyn, L. (1974). "Zoning and Housing Costs," in Listokin, D. (ed.), Land Use Controls: Present Problems and Future Reform, (New Brunswick, N.J.: Rutgers University, Center for Urban Policy Research).

Sullivan, A.M. (1990). "Victim Compensation Revisited: Efficiency versus Equity in the Sitng of Noxious Facilities," Journal of Public Economics, Vol. 41, No.2, pp 211-225.

Sun, (1982), "Radwaste Dump WIPPS up a Controversy," Science, Vol. 215 (March), pp 1483-1484. 
Swallow, S.K., Opaluch, J.J. and Weaver, T.F. (1992). "Siting Noxious Facilities: An Approach That Integrates Technical, Economics, and Political Considerations;" Land Economics, Vol. 68, No.3, pp 283-301.

Tabor, R. (1979). "Infrastructure Planning," in Getzels and Thurow (ed.), Rural and Small Town Planning, (Chicago, American Planning Association; Planners Press).

The Palm Beach County Waste Authority (1986). A Study of the Impact of Iransfer Atations on Sorrouding Residential Property, prepared by Callaway and Price, Inc. (West Palm Beach, Florida)

Thisse, J.F. and Zoller, H.G. (1983). "Some Notes on Public Facility Location," in Thisse, J.F. and Zoller, H.G. (ed.), Locational Analysis of Public Facilities, (New York; North-Holland Publishing Company).

Tiebout, C.M. (1956). "A Pure Theory of Public Expenditure," Journal of Political Economy, Vol. 64, pp 416-424.

U.S. EPA (1972). The Effects of Solid Waste Disposal Sites on Property Values, prepared by General Behavior Systems, Inc. (Washington, D.C.).

U.S. EPA (1975). Measuring the External Effects of Solid Waste Management, prepared by Schmalensee, R., Ramanathan, R. Ramm, W. and Smallwood, D. (Washington, D.C.).

U.S. EPA (1991). 40 CR Parts 257 and 258; Solid Waste Disposal Facility Criteria Final Rule in Federal Register, Vol. 56, No. 196.

Vaughan, C.E. (1984). Base 1000: The Vaughan Method of Appraising Houses, (Reston Publishing Co., Reston, Virginia).

Von Thunen, J.H. (1966). von Thunen Isolated State (Peter Hall, trans.) New York: Pergamon Press. 
Waldo, R.D. (1974). "Urban Land: Values and Accessibility," Land Economics, Vol. 50 (May), pp 196-201.

Walls, M.A. and Marcus, B.L. (1993). "Should Congress Allow States to Restrict Waste Imports," Resources, Winter, pp 7-11.

Wetmore, R.D. (1980). "Massachusetts's Innovative Process for Siting Hazardous Waste Facilities," Environmental Impact Assessment Review, Vol. 1, No.2, pp 182-184.

Witte, A.D., Sumka, H.J., and Erekson, H. (1979). "An Estimate of a Structural Hedonic Price Model of the Housing Market: An Application of Rosen's Theory of Implicit Markets," Econometric, Vol. 47, pp 1151 1173.

Weisberg, B. (1993). "One City's Approach to NIMBY: How New York Developed a Fair Share Siting Process," Journal of the American Planning Association, Vol. 59, No.1, pp 93-97.

Wolpert, J. (1978). Group Homes for the Mentally Retarded: An Investigation of Neighborhood Property Impacts (New York; New York State Office of Mental Retardation and Development Disabilities). 


\section{APPENDIX}
A. Regression of Model 1: 1971 data
B. Regression of Model 2: 1979 data
C. Regression of Model 3: 1986 data
D. Regression of Model 4: Combined 1971, 1979 and 1986 data
E. Regression of Model 5: 1979 data - sale price adjusted to 1971 price level
F. Regression of Model 6: 1986 data - sale price adjusted to 1971 price level
G. Regression of Model 7: Combined 1971, 1979, 1986 data - sale price for 1979 and 1986 adjusted to 1971 price level 


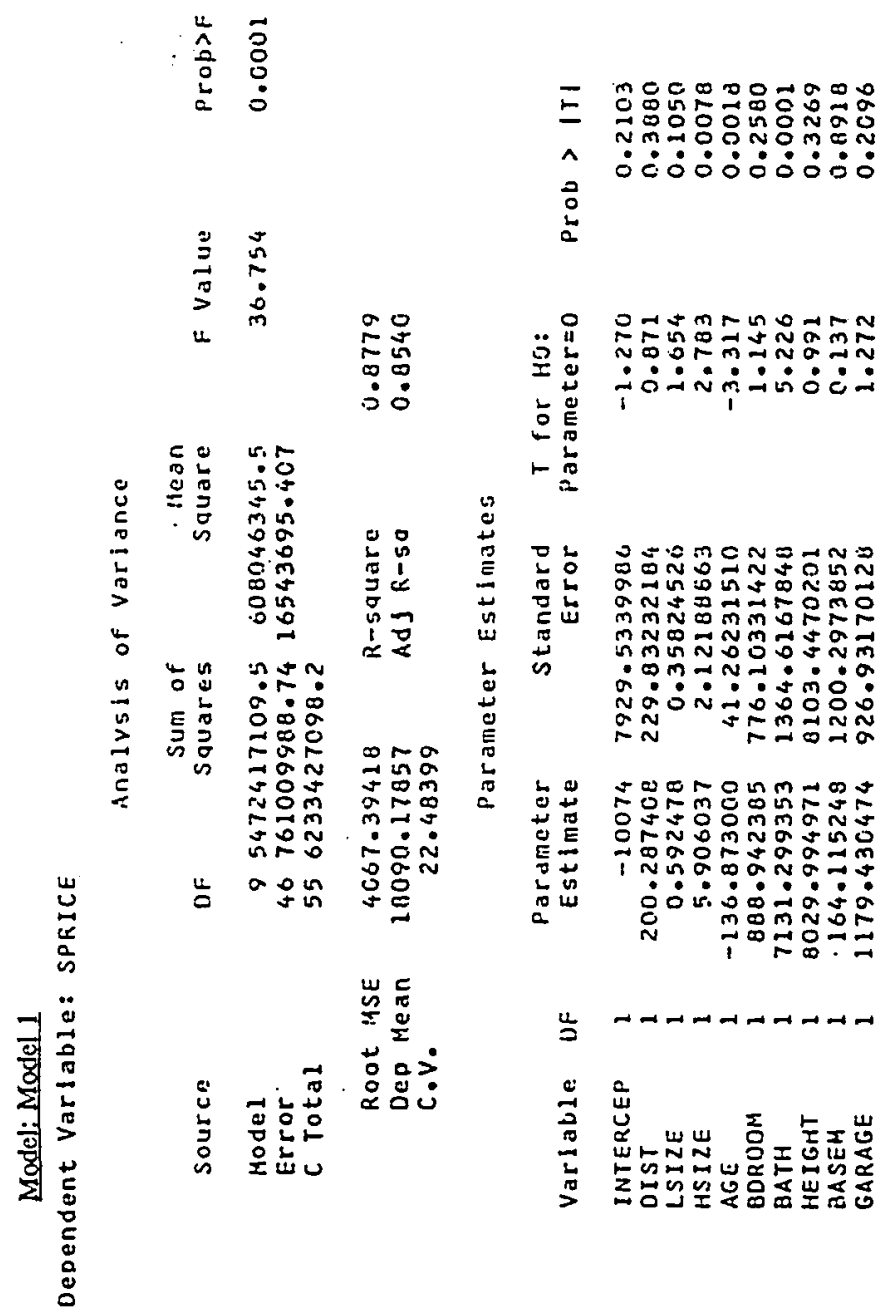




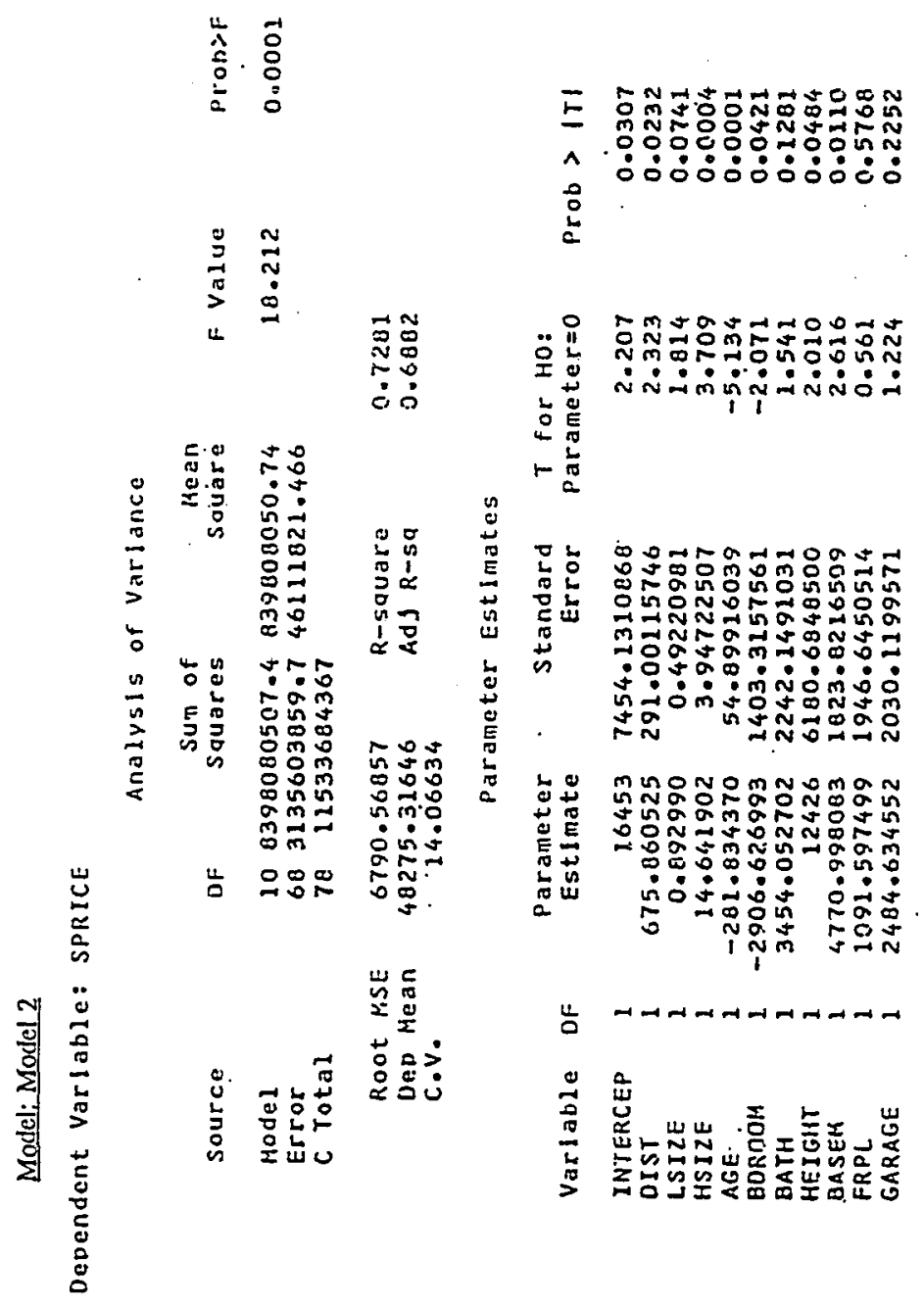




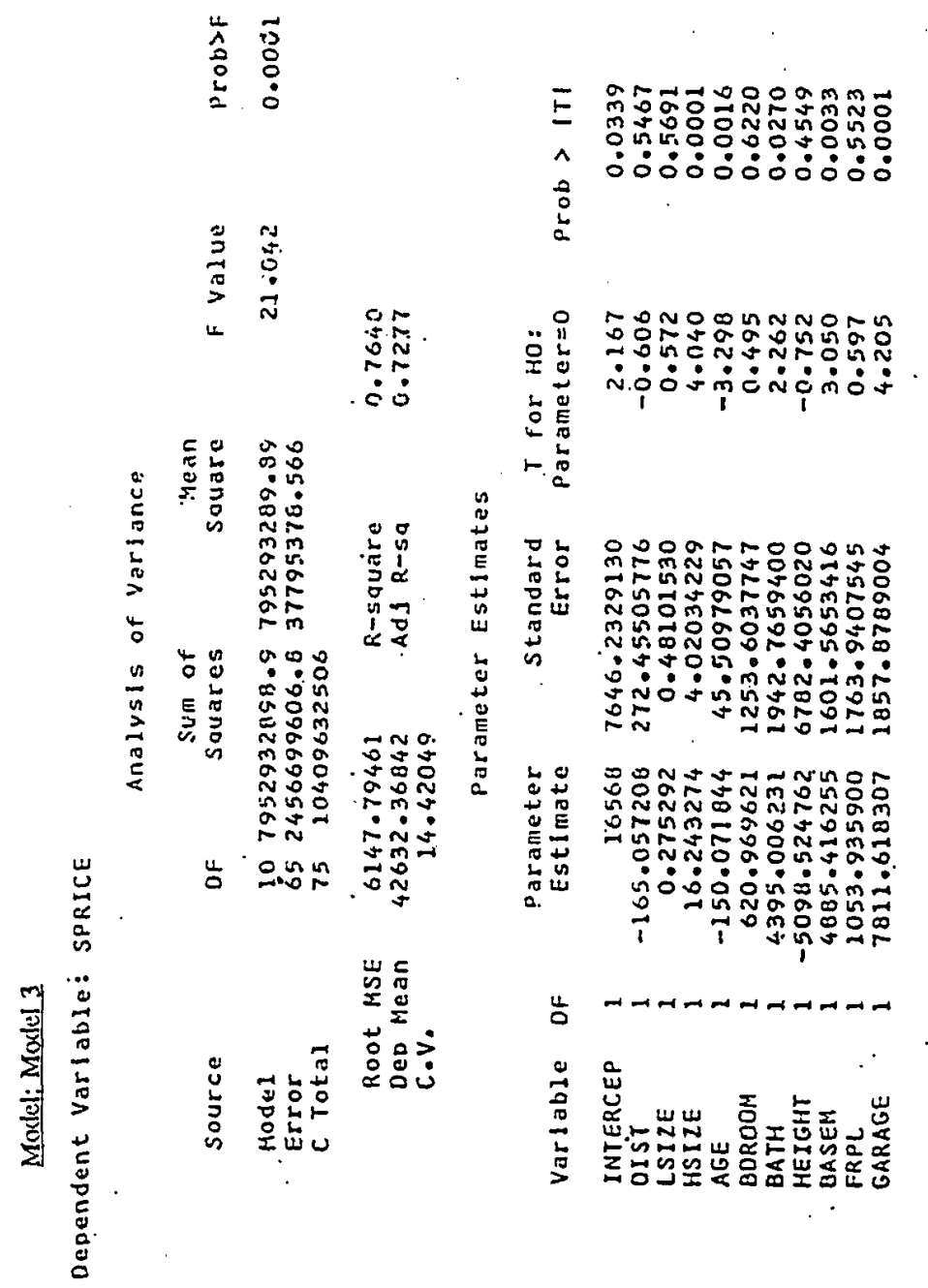




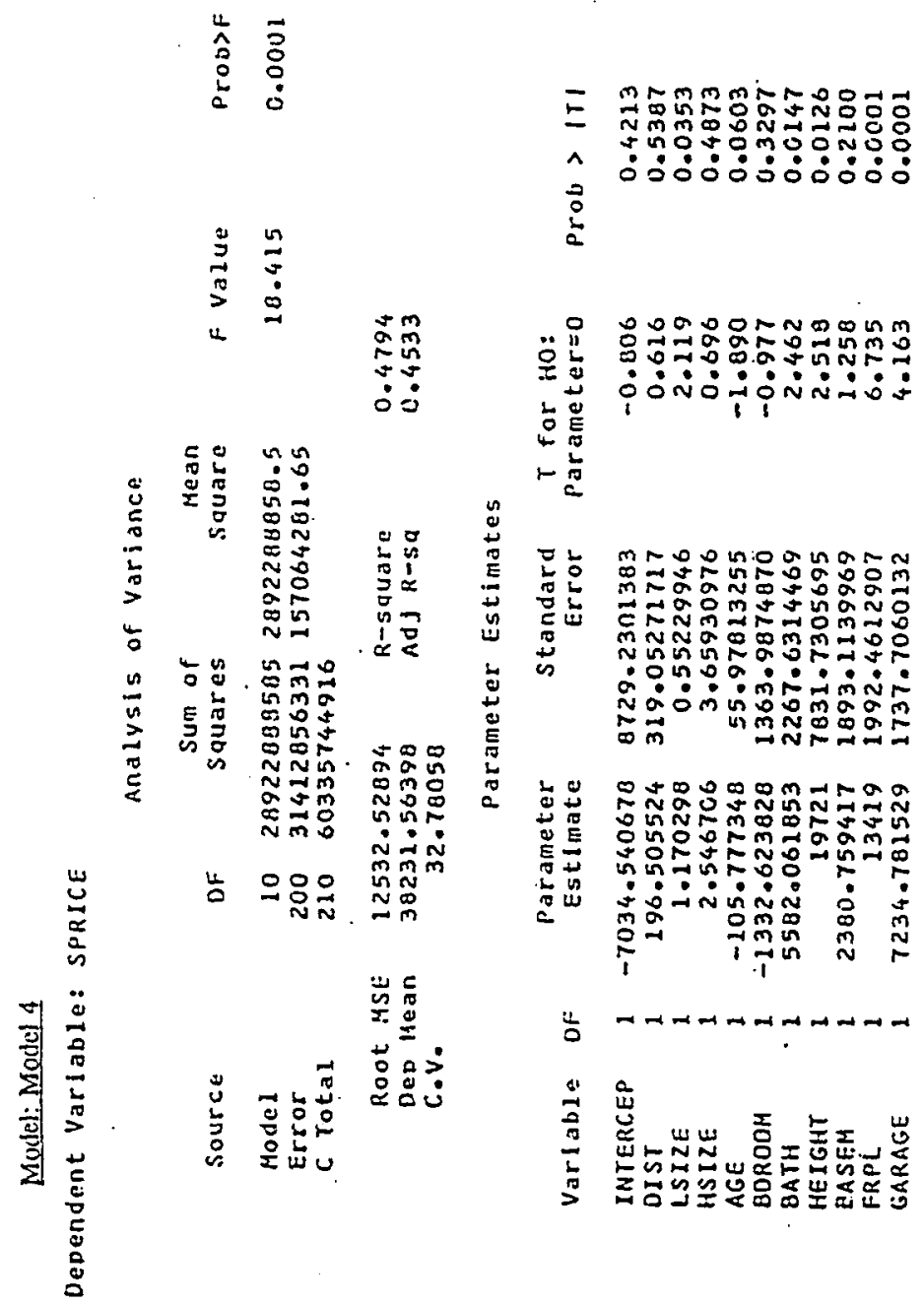


FINDINGS FOR 1979 MODEL

[Sale Price Adjusted 10 1971 Price Level)

Model: Model 5

Dependent Varlable: PRICr

Analysis of Varlance

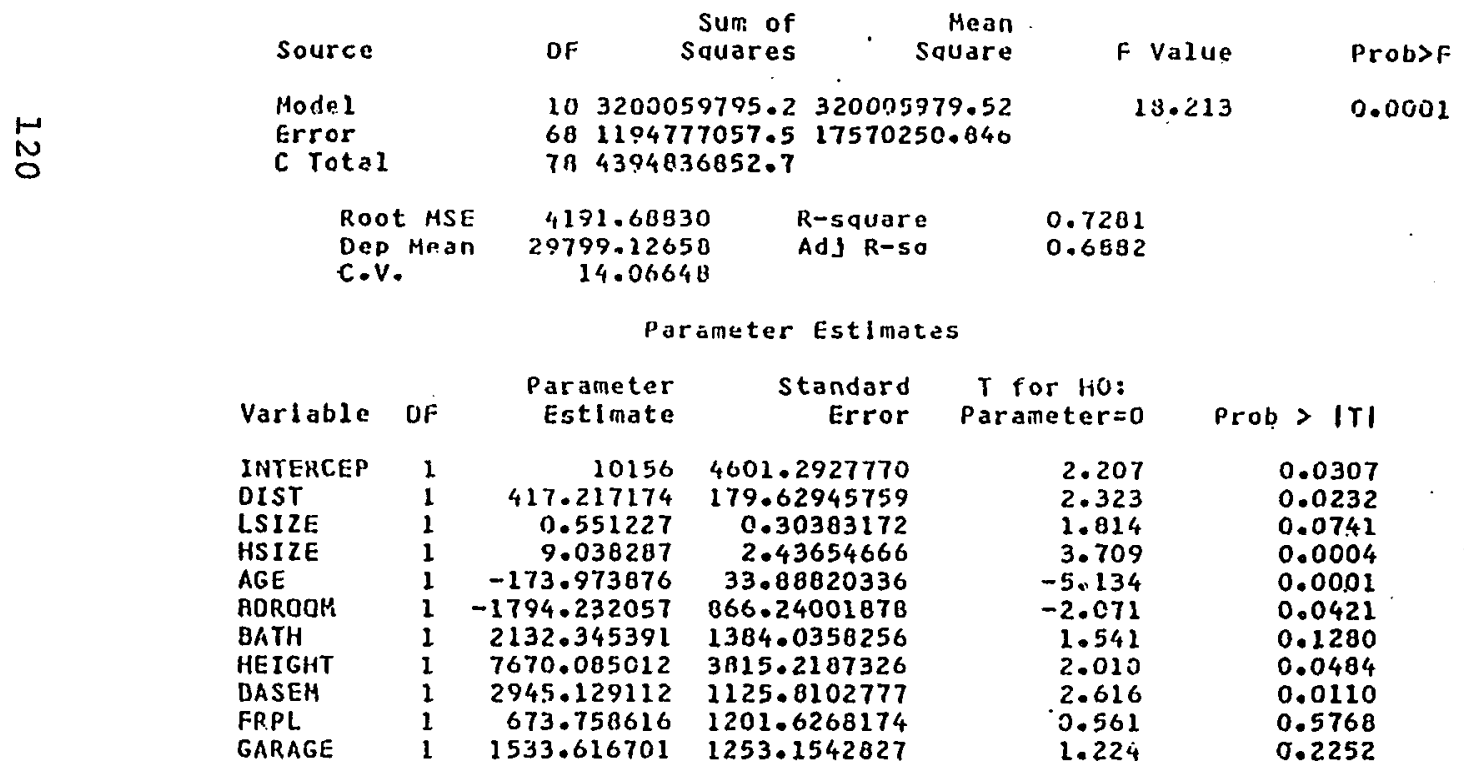




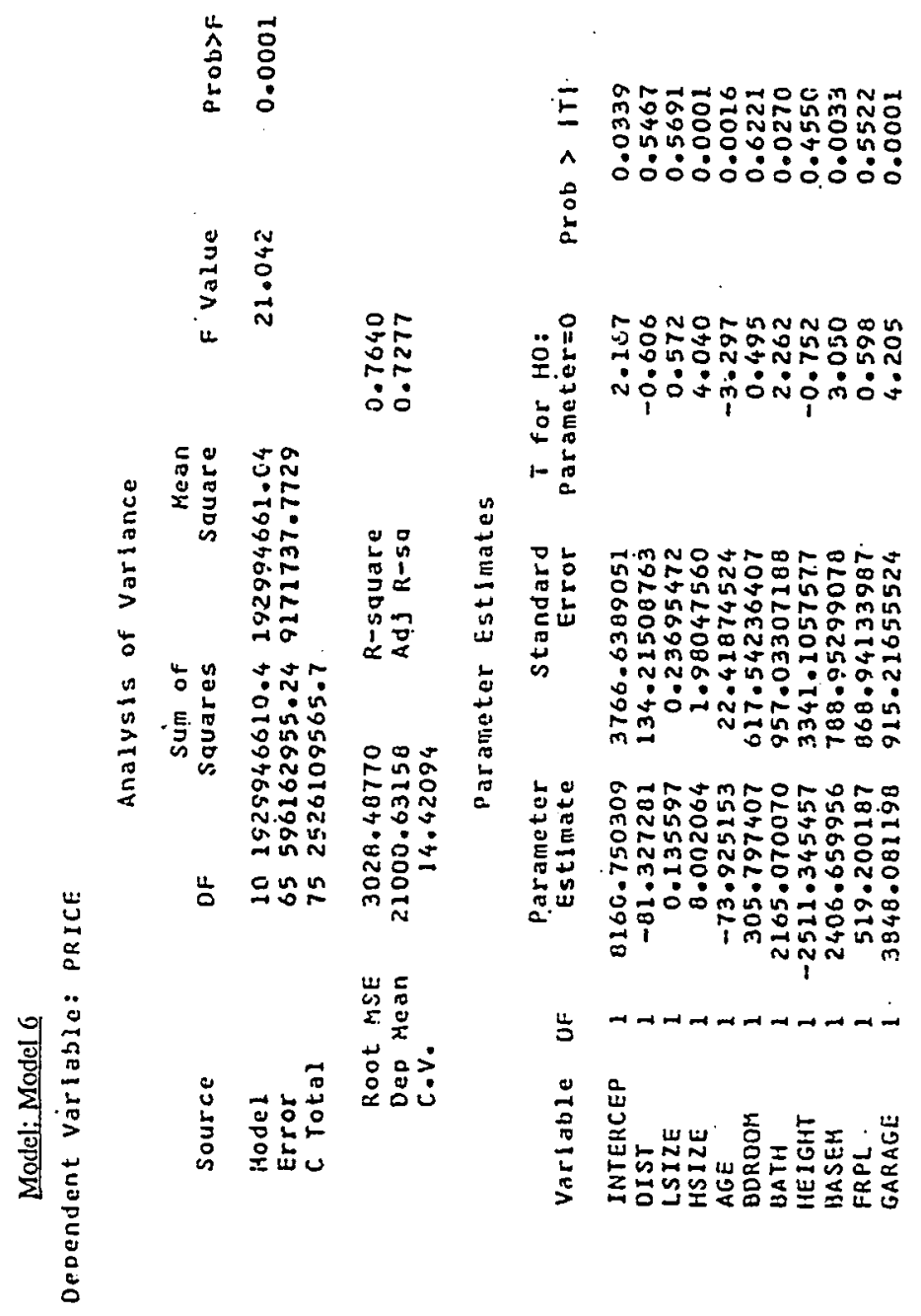


FINDINGS FOR 1971, 1979 and $1986 \mathrm{MODIL}$

Silc price for 1972 and 1986 Adjusted to 1971 Price Level

Model: Model 7

Dedendent Varlable: SPRICE

Analysis of Variance

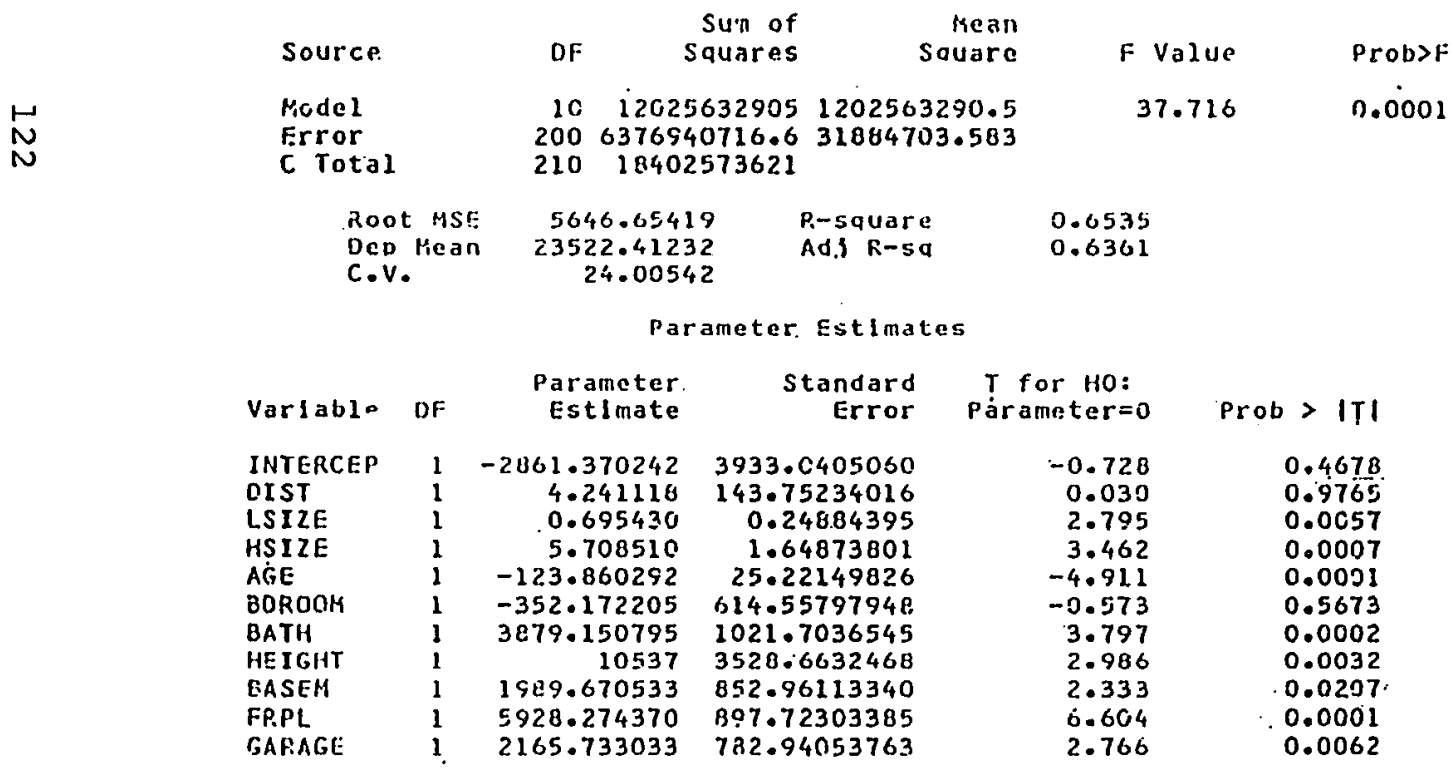

